Article

\title{
Global Halal: Meat, Money, and Religion
}

\section{S. Romi Mukherjee}

Maître de conférences, L'Institut d'études politiques de Paris, 27 rue St. Guillaume, Paris 75007, France; E-Mail: romi.mukherjee@sciencespo.fr

Received: 28 October 2013; in revised form: 30 December 2013 / Accepted: 6 January 2014 /

Published: 29 January 2014

\begin{abstract}
The following article deconstructs (and demystifies) Halal with a view to unraveling how the religious, racial, economic, and ethico-political are articulated in and around material technologies of meat production and bodily techniques of religious consumption/the consumption of religion. It, thus, attempts to rethink the nexus of food, politics, and contesting visions of the sacred and the profane, from within the folds of the global and global Islam. Halal emerges as a terrain replete with paradigmatic juridical and political questions about the impasses of social and culinary conviviality and cosmopolitanism. Although there is certainly nothing new about religious taboos on food on the body, Halal is far from being a personal or strictly communal set of strictures and practices. On the contrary, global Halal emerges as a new agonistic field typified by charged debates concerning the place of secularism, recognition, and "food diversity" in the global marketplace. This paper offers a cartography, both phenomenological and social scientific, of this multi-tiered site of meat, power, and belief.
\end{abstract}

Keywords: meat; Islam; the sacred; consumption; taboo

\section{Introduction: From Meat to Spiritual Capital}

Halal, literally meaning lawful or licit in Arabic, functions as a constitutive element of Islamic law. It delineates a vast array of taboos which entrench themselves as socio-religious hygienes that cordon off and define the purity of the body and being. While lodged in the very tissue of quotidian life, the taboo is most commonly associated with meat production and consumption. More specifically, Halal is generally considered to refer to the interdiction on pork and Muslim ritual slaughter. As innocuous as this may appear, Halal's specificity emerges in the complexity of its production and supply chain, its discursive construction as a means of thinking through the politics of belonging and exclusion, and the 
veritable multi-billion dollar market within which the religious code and its concrete deployment, meat, circulate. This chain which traverses a series of sacred points or stages is comprised of, inter alia, particular forms of animal husbandry, a religious slaughter which must confine to the strictest of guidelines, the certification by "Halal experts", imams, or monitoring committees, distribution by national and multinational Halal corporations, the trust forged between the butcher and the consumer during the purchase, and finally, the dining table itself.

In the same manner that the veil (hijab) proved to be much more than a simple piece of clothing, "global Halal" cannot be reduced to a culinary idiosyncrasy of the Muslim carnivore. Halal is not simply about meat. It emerges as an ethos, a site of political and spiritual contestation (both internal and external), a bodily technique, a traditional, yet radically, post-modern quest for authenticity, and above all, a means of establishing firm lines of demarcation between the imaginary of the pure body and the imaginary of corrupted global world. Hence, Halal permeates Islamic strictures on sexuality, etiquette, gesture, medical ethics, marriage, and, of course, meat. It is the fetishisation of the taboo, a taboo, which, if properly adhered to, magically tones up the moral, spiritual, and biological tissue of the body and being. These strictures have become progressively solidified with the expansion of global Islam. However, the permanence of the interdiction, its sanctity and staying power, are subject to a series of recalibrations; when deployed against the backdrop of globalization, the taboo between halal and haram must become, like global subjectivity, ever adaptable and supple.

Such suppleness is a necessary demand for a global and globalizing Islam and a threat to its capacity to guard the trans-historical impermeability of the taboo. Halal is a type "work" or labor wherein religious leaders and institutions struggle to uphold and embolden the opacity of the taboo in a context whose very substance is transgressive. As for believers, they must hone and train their psyches and bodies to only imbibe, ingest, and incarnate Halal while engaging in never-ending struggle to purge their quotidian lives of the perceived impurities of late capitalism and the secular world. Doyens of Halal engage in further "work" to outbid their competitors and coerce the umma, brandishing the taboo and their rendering of it as the only path towards redemption. In the interstices of these vituperations, Halal is a matter of "trust;" trust in the purity and standards of the product, trust in the purity and standards of religious leaders and slaughterers, trust in the promise of Halal, etc. Trust in Halal may also move in synchrony with the radical distrust of global secularism and even fellow "people of the book" with whom the believer may only embrace in rhetorical forms of solidarity. However, just as trust can be violated while appearing to be preserved, the socio-religious logic of Halal implies the existence of the interpellation of the Law as logos and the practice of the law in the day-to-day rumblings of the contemporary world. Supple and subject to a litany of contingent criteria concerning the pure and the impure, Halal, for global Islam, is also a matter of degrees.

Slavoj Zizek suggests, that "with Islam, it is no longer possible to ground a community in the mode of Totem and Taboo...this problem is at the very heart of the (in)famous umma...it accounts for the overlapping of the religious and the political (the community should be grounded on God's word), as well as for the fact that Islam is 'at its best' when it grounds the formations of a community 'out of nowhere', in the genealogical desert, as the egalitarian revolutionary fraternity — no wonder that Islam succeeds when young men find themselves deprived of a traditional familial safety network ([1], p. 115). Globalization is one such genealogical desert. Amongst its most visible processes of desertification are those which strike at the very core of religious life: the scouring of religious memory and its imagined 
intimacy to a hallowed point of origin, the encroachment of market-logics onto religious life and practice, the destabilization of religious place and space by new modes of transnationalism and flexible labor, processes of mixity and syncreticism, and the need for "portable religion." In such a "global desert", Islam does indeed "come out of nowhere" and, certainly in the European context, erects itself as an antagonist in an ongoing war for the minds and hearts of second and third generation Arabs and countless new waves of diaspora. Here, Halal presents itself as one "grounding" mechanism whose efficacy lies in its utter simplicity and embeddedness in the structures of everyday life (cleanliness, food, intimacy, beauty, etc.). From a phenomenological perspective, it is a means of being at once in globalization and outside of it, a means of participating in the great brotherhood through dietary choices, and a means of sacralizing corporal and psychic interiority in an external world seemingly devoid of the sacred. Halal is a strategy - a means of imagining the integrity of identity, body, and spirit in a hyper-modern landscape where such normative notions exist only to be shattered as false absolutes that run against the grain of the logic of flows, fluxes, and infinite mutability. Halal is global, but is expressed through a veritable practical ethics whose structure is both personal and communal. A shifting dialectic of inside/outside, its firm grounding remains impossible and incomplete. As such, Halal offers the occasion for great solidarity and is also the cause for great neurosis.

Above all, however, Halal is spiritual capital and its distribution and dissemination are assured by a global apparatus of Halal food production and verification. Yet, this is no "niche market". As of 2004, the global Halal market sold its goods to approximately 1.5 billion consumers ([2], p. 31). According to a 2011 study by Kambiz Heidarzadeh Hanzaee and Mohammad Reza Ramezani, the global Halal Market is estimated to be worth 150 billion dollars per year and continues to grow $2.9 \%$ annually; the Halal certification industry continues expands in unison and, at the time, was already constituted by 100 certification agencies ([3], p. 2). Noting also that McDonald's, Taco Bell, KFC, and other fast food chains have seen a massive influx in profits through included Halal-friendly burgers, tacos, and chicken, Hanzaee and Ramezani ultimately argue that the dispositif of food and religion cannot be avoided in the secular public sphere and, given the money to made, businesses across the world should consider entering into the Halal industry ([3], p. 2). In short, the world should embrace Halal, because it can get rich from Halal and its religious resonances should be eschewed in the name of massive profits. This is indeed a clever line of argumentation, but it subtextually poses a rather obvious, but important question: is Halal simply another good to be exchanged for profit in the global free market or does profiting from Halal coincide with the exchange and circulation of much more than a couple of happy meals?

On the one hand, the nexus of Halal is constructed and deployed through the dialectical rapport between the ingestion of spiritual capital and the sought after monopolies on industrial, economic, and spiritual capital in the "Halal business". For instance, a Bourdieusian approach to the global expansion of the Halal industry would argue that it is from within the nexus of Halal certification, the endorsements of mullahs and sheiks, and the word of mouth of consumers, that one Halal authentication service, one butcher, and one brand, comes to establish a monopoly on both meat and religious production; the Halal industry administers a certain alimentary sacred, and various agents and actors within the industry pin themselves against one another in an attempt to legitimate the purity of their foods and their faiths ([4], pp. 10-12). On the other hand, the rise of global Islam and the appearance of dense conglomerations of Muslims in its changing geography certainly demand that the 
CEO's of fast food restaurants and other dining establishments rethink the basic principles of demographics and supply and demand. Walter Benjamin was correct to recast capitalism as a religion. However, what he could not have envisaged was how capitalism is coextensive with a spirit of liberal neutrality, a neutrality which allows for entrepreneurs to sell their goods, religious or otherwise, in the name of greater profit. Potentially giving new meaning to the phrase "bad faith," the Halal market is also bolstered by those businesses and chains that have no religious pretensions whatsoever but simply respond to the demand of their customers. In principle, this should have no moral implications unless one decided that it mattered what Ronald McDonald believed and interrogated the rapport between his faith and his burgers. Conversely, however, when it comes to Halal, for the believer, the relationship between faith and burgers is inexorable and inexorably demanding.

Halal has become the "meat of religion and politics" in Europe and its most dramatic repercussions have been felt in the epicenter of global Islam's collision with the secular world and the "secular Republican sacred" France. Many Frenchmen recoil in horror at the mere thought of the Celtic coq, a symbol of France's mythic Gallic origins, being ritually slaughtered by someone screaming Allah Akbar. Better for them that the coq be debeaked and mutilated at an industrial poultry factory (thus immediately plunging one into the domain of the animal ethics of ritual sacrifice an industrial modes of husbandry). Although many liberal proponents of diversity and boutique multiculturalists, ever eager to sample the newest in ethic food fare, deem Halal to be a natural extensions of globalism's will to pluralism, Gilles Kepel suggests that Halal is also something of a "silent revolution"; less mediatized, but no less visceral than the hijab, Halal too "developed in its own logics of communitarian elaboration" and "in lieu of directly confronting French secularism on the terrain of education and politics, it constructs itself from below, in part through the sedentarization of Muslim families in the mid-1970s...it produces itself through complex economic processes where religious organizations struggle to control a process dominated by commercial strategies of meat negotiation" ([5], p. 76). ' Similar suspicions about Halal and its orchestration of a new type of ethnic, religious, and dietary apartheid have been voiced in Belgium, Germany, and certain parts of the United States. In a more general sense, for many non-Muslim Europeans and Americans, the "Halal effect" is also a question of "degrees of tolerance and compromise" where the proliferation of Halal butchers, Halal-friendly public policy, and Halal fast-food restaurants, represents the next subterranean phase of the much-touted territorial expansion of Islam. The confrontation between Global Empire and its supposed adversaries is waged on the terrain of beef, chicken, lamb, and veal. And the sacredness of the secular world, embodied in its right to culinary and bodily profanation, rubs uncomfortably against, the sacrality of Halal.

This paper offers a cartography, both phenomenological and social scientific of this multi-tiered marketplace of meat, power, and belief. It ultimately argues that the border that Halal imagines between the pure and the impure transcends the production and consumption of meat. Rather, it contends that Halal, as a discourse, code, and way of engaging with the world, has serious

1 The title of Kepel's latest essay obviously evokes the last novel written by Victor Hugo and thus, sub-textually orients the French Banlieue known as the "93" as the site of the next counter-revolution with its predominately Muslim populations as the arbiters of the next reactionary offensive against the Republic. Kepel's comments in Halal are also collected in a section of the text entitled "Un saison en banlieu," making obvious reference to Arthur Rimbaud's "Un saison en enfer." 
consequences on the manner in which community and civil life are conceived of in both national and transnational contexts. Gastronomy becomes the new site from which anxieties about both Global Islam and the perceived waning opacity of Western secularism are negotiated. In the politics of Halal, meat is further transformed into a screen where the failures of multiculturalism and diversity policy are engaged, albeit in an opaque and highly tendentious manner.

At stake for the believer is "authenticity", an untenable and flawed concept, which, as I argue, in its will to glorious distinction and hierarchization can only lead to a type of psychic death; the spiritual capital amassed in the name of authenticity masks the presence of a deep phobia about our bodies and those of animals, a phobia of the rough ground and often impure naturalness of something called nature. At stake for the non-believer, however, is not necessarily a defense of such nature, but a defense of his "freedom to choose", his "freedom to profane" and his right to be profane(d). Yet this freedom may be deployed to isolate and exclude "others" and become the motor for perceived forms of moral or "sacred" injury. A host of actors polarize the debate: politicians, slaughter-men, certifiers, journalists, imams, cyber-prophets, sociologists, and of course, the members of the umma (which is far from monolithic or homogenous). All recognize, for unique politico-religious reasons, that the sacred and the profane must be rigorously set apart. All equally recognize that such a task proves complex, if not impossible, in a global marketplace characterized by the comingling and mixity of identities and values. However, Halal is not only a type of boundary-work performed in such a marketplace, but also a global marketplace itself whose expansion seems to be indeed boundless. In this sense, it is the globalization of a taboo, one whose mobility and often opaque internal logics continue to confound and elicit charged debates on everything from the future of the Occident to cheeseburgers.

\section{The Interdiction: Of Pigs and Human Animals}

The rapport between food and the construction of various forms of metaphysical and social hierarchy has emerged as a minor yet important tradition in the study of material and ritual cultures. ${ }^{2}$ The fundamental insight that binds theorists of religion and theorists of food concerns food's symbolic function in the construction of inter-personal and inter-communal boundaries and the larger social usages of food culture in identifying selves and others. Food, a basic human need and site of repetition and rites, is imbricated with deep moral, aesthetic, and mnemonic dimensions. It is that around which taste, class, and privilege are coded. Its presentation and ingestion demand cleanliness, decorum, and the proper distribution of portions. Certain foods are bound to place and the past and their olfactory and sensorial mana can inspire both wistful nostalgia and rabid nationalism. Solid or liquid, raw,

2 See inter alia, William Robertson Smith, Lectures on the Religion of the Semites (1889), Emile Durkheim, Les formes élémentaires de la vie religie use (1912), Claude Lévi-Strauss, Le Cruit et le cu it (1964) and «Le triangle culinaire» (1965), Mary Douglass, Purity and Danger: An Analysis of Concepts of Pollution and Taboo (1966), and "Deciphering a Meal” (1971), Louis Dumont, Homo Hierarchus: Essai sur le système des castes (1967), Jonathan Z. Smith, To Take Place: Toward Theory in Ritual (1987), Carolyn Walker Bynum, Holy Feast and Holy Fast: The ReligiousSignificance of Food to Medieval Women (1987), Margaret Visser, The Rituals of Dinner (1992), Ronald Grimes, Deeply into the Bone: Re-inventing Rites of Passage (2000), Claudia Roden, The Book of Jewish Food: An Odyssey fromSamarkind to New York (1996), Catherine Bell, Ritual Theory, Ritual Practice (1992), and Kathleen E. Corly,Private Women, Public Meals: Social Conflict in the Synoptic Tradition (1993). 
cooked, or over-cooked, civilized or barbarian, food, and the taboos that it inevitably engenders, are essential mechanisms for the instauration of imagined modes of social organization and disorganization. And, while food has become increasingly secularized in the global "food court", it, like religion, still operates as a type of communication and locus of communion. Yet, in the accelerated secularization of food and food consumption, the confusion that reigns between the factory, the altar, the fast-food restaurant, and the larger world of the illicit, has still not quelled the force of anti-pig sentiment.

Simultaneously, sensitivity to the eating habits of others has become another form of commonplace correctness demanded by global ideology's discourse of tolerance and pluralism. Most major airlines, for instance, offer a myriad of in-flight special meals which take into account the evolving politics of "dietary restriction": vegetarian, organic, kosher, diabetic, low fat, low sodium, carbohydrate-free, lactose-free, gluten-free, peanut-free meals, and of course, Halal "Muslim meals". Some meals respond to medical conditions while others respond to religious conditions. However, while kosher and Halal may be aligned by their consumption by "people of the book", the latter's appropriation by political Islam has transformed this seemingly innocuous "restriction" into a site of contestation between the sanctity of the umma and the world outside of it which is inhabited by pigs and those who eat pigs.

The unease with pigs, pork, and swine has historically never been restricted to Islam and indeed, as Frederic J. Simoons remarks, anti-pork feeling pervaded the Near East previous to its inscription in hadith; long before the book of Leviticus, the rhetoric of unholy pigs was also evinced in the early Indo-European world, in various Greek and Roman cults, and amongst the Egyptians and the Assyrians ([6], pp. 14-22). Although the taboo was maintained by Judaism, the pig would slowly become, in varying degrees, acceptable amongst the cults of the ancient world and amongst many Christians as well. Yet, with the establishment of Islam, the Prophet Mohammed, "seeking to imitate Jewish food laws," became "the champion of the ancient negative attitudes towards the pig and pork" and "the pig was the only animal singled out this way in the Koran, where the ban was repeated more than once" ([6], p. 32). Beyond the tautological arguments that dictate that pigs are illicit because they are filthy, anti-pig attitudes in early Islam were crystallized through a vast nexus of governmentality, ecological concern, dermatological and digestive worries, and the need to quell the rabble. For Paul Diener and Eugene Robkin, porcophobia was a deliberate mechanism instrumentalized to control the lower classes, bind them to the burgeoning metropolis, and destroy the possibilities of rival clans and communities through a clever funneling of all rural agricultural surplus into the city ([7], pp. 501-04). Marvin Harris further insists that Islamic food taboos must be read against the backdrop of the eco-systems in which they are deployed, arguing that,

Wherever Islam has penetrated to regions in which pig raising was a mainstay of the traditional farming systems, it has failed to win over substantial portions of the population. Regions such as Malaysia, Indonesia, the Philippines, and Africa south of the Sahara, parts of which are ecologically well suited for pig raising, constitute the outer limits of the active spread of Islam. All along this frontier the resistance of pig-eating Christians has prevented Islam from becoming the dominant religion. In China, one of the world centers of pig production, Islam has made small inroads and is confined largely to the arid and semiarid western provinces. Islam, in other words, to this very day has a geographical limit which coincides with the ecological zones of transition between forested regions well suited for pig husbandry and regions where too much sun and dry heat make pig husbandry a risky and expensive practice ([8], p. 78). 
Building on Harris' insights, Richard A. Lobban further argues that the low social capital afforded to pigs in arid and dry climates ultimately serves to not only legitimate the taboo but also produce a cycle wherein pigs are deliberately fed wastes and forced into perpetual abjection ([9], p. 71). That is, pigs were always doomed to ill-health, cursed into squalor, and forsaken. Hence, their consumption was readily linked with toxins and parasites, which, according to some fanciful mythologies, not only inflict great bouts of stomach pain and deform otherwise perfect skin, but prove fatal. In naturalizing these legends through religious dictums concerning the world of Allah, his good things, and radical evil, Islam ultimately forged a means of consolidating the belief and surplus of the umma in a very real desert. Furthermore, in doing so, it set itself off from the other monotheisms and quashed any criticisms that it was nothing more than a confused amalgam of previous traditions. Or, as Simoons, for instance, concludes, the porcophobia of the Prophet and his commentators functions as a hyperbolic strategy of distinction:

Whatever factors led to the ban's introduction, it served to distinguish Moslems from their Christian adversaries, and from the seventh century onwards it was rapidly diffused by the faithful from an essentially pigless Arabia into regions of pig-keeping in Asia, Africa, and Southern Europe...some Moslems, such as those of Egypt, so abhorred swine as to consider everything touched by them contaminated and worthless...Venetian merchants were required to pay a substantial sum for the right to keep a pig at their establishment in Alexandria ([9], p. 33, my emphasis).

Halal and Haram already had global currency in the days of the Rashidan and Umayyad Caliphates. Pig-taxes, a variation of jizyah (taxes levied against all Christian and Jews), were a means of symbolically registering the authority of the caliphate, but also of profiting from the illicit and, indeed, buying conversions. Halal, from its earliest inception, was a useful way to line the coffers of Islamic expansion in the Christian world, a world that was contaminated, defiled, and Haram. The mystery concerning the real socio-political origins of the ban's introduction also gives credence to the argument that the taboo may have been geopolitical in nature; the pig's supposed intrinsic illicitness is the result of a thorough calculus of ecological, spiritual, and social capital. The practice of Halal in the cosmopolitan early Mediterranean world and its practice in the cosmopolitan global world, nevertheless, illuminate how geopolitical strategies of distinction are incarnated in bodily practice and dietary ritual, how the body and its intestines are sites of political-theological recuperation. Halal is erected as a politico-ontology, one which binds the caliphates will to political absorption to the absorption of food.

Halal is a mode of religious, political, and bodily classification. It is an elaborate machine of taxonomy that hierarchizes and divides the material world through appeals to the transcendent. For Durkheim and Mauss, moreover, primitive classifications "are systems of hierarchized notions" and "these systems, like those of science have a purely speculative purpose...such classifications are thus intended, above all, to connect ideas, to unify knowledge" ([10], p. 81). Halal is one such speculative site of classification whose unification of hygienic and dietary knowledge equally serves to unify the umma through inscribing the law onto the body. Halal must be read then as a bio-political strategy which unifies populations of believers through the cultivation of a global habitus of religious know-how. 
The central principles of Halal, from the slaughter to the supper, are by and large captured in the following verses where the workings of such speculative classification are explicit:

People, eat what is good and lawful [Halal] from the earth, and do not follow Satan's footsteps, for he is your sworn enemy ([11], p. 26).

He has only forbidden you carrion, blood, pig's meat, and animals over which any name other than God's has been invoked. But if anyone is forced to eat such things by hunger, rather than desire or excess, he commits no sin: God is most merciful and forgiving ([11], p. 26).

You are forbidden to eat carrion; blood; pig's meat; any animal over which any name other than God's has been invoked; any animal strangled, or victim of a violent blow or a fall, or gored or savaged by a beast of prey, unless you still slaughter it [in the correct manner]; or anything sacrificed on idolatrous altars. You are also forbidden to allot shares [of meat] by drawing marked arrows - a heinous practice-today the disbelievers have lost all hope that you will give up your religion. Do not fear them: fear Me. Today I have perfected your religion for you, completed My blessing upon you, and chosen as your religion Islam: [total devotion to God]; but if any of you is forced by hunger to eat forbidden food, with no intention of doing wrong, then God is most forgiving and merciful ([11], p. 79).

They ask you, Prophet, what is lawful for them. Say, 'All good things are lawful for you.' [This includes] what you have taught your birds and beasts of prey to catch, teaching them as God has taught you, so eat what they catch for you, but first pronounce God's name over it. Be mindful of God: He is swift to take account ([11], p. 79).

You who believe, do not forbid the good things God has made lawful to you- do not exceed the limits: God does not love those who exceed the limits ([11], pp. 88-89).

So [believers] eat any [animal] over which God's name has been pronounced, if you believe in His revelations ([11], p. 103).

... and do not eat anything over which God's name has not been pronounced, for that is breaking the law ([11], p. 103).

[Prophet], say, 'In all that has been revealed to me, I find nothing forbidden for people to eat, except for carrion, flowing blood, pig's meat — it is loathsome — or a sinful offering over which any name other than God's has been invoked.' But if someone is forced by hunger, rather than desire or excess, then God is most forgiving and most merciful ([11], p. 106).

He has forbidden you only these things: carrion, blood, pig's meat, and animals over which any name other than God's has been invoked. But if anyone is forced by hunger, not desiring it nor exceeding their immediate need, God is forgiving and merciful ([11], p. 106).

The leitmotif of the lawful and non-lawful, which permeates the text, is further applied to marriage and chastity regulations, sexuality, and all "good things". It also contains lengthy and highly ambivalent passages on mushriks (polytheists and pagans who may come to believe) and mushbhoo (the doubtful and suspect), which are equally invoked in relation to Halal. In dramatically distinguishing between two worlds, and distinguishing itself from its religious Others, Islam and the nexus of Halal thus prove, as Mary Douglass famously noted, that "where there is dirt, there is system" ([12], p. 35). 
Of course, pigs, along with carrion, are both textually and socially recognized as the lynchpin of the Manichean universe between Halal and Haram, and are replete with a "sin" that cannot be ritually exorcised (although, in hunger related death the law can be suspended-better for a believer to be defiled than to die). Yet, the underlying logic of the taxonomy or classification remains unclear. To all those who claim that the pig's inherent filth and propensity for disease or trichinosis exclude it from Halal, let it be known that the world of licit animals cannot in any way be considered to be intrinsically cleaner than the pig. Harris equally observes how the porcophobia of Halal is menaced by contradiction: "In domesticating the pig, Jews and Moslems left unexplained their more tolerant attitudes towards other dung-eating domesticated species. Chickens and goats, for example, who given motivation and opportunity, also readily dine on dung. The dog is another domesticated creature that easily develops an appetite for human feces. And this was especially true in the Middle East, where dung-eating dogs filled the scavenging niche left vacant by the ban on pigs. Jahweh prohibited their flesh, yet dogs were not abominated, bad to touch, or even bad to look at, as were pigs" ([8], p. 68). The rancor projected at the pig is actually roused by the pig's ostensible liminal status and its capacity to confound the taxonomic schemes that produce Halal. The pig is not necessarily "dirty". Rather he is the excess that destabilizes the sanctity of the system.

Pigs are extremely social animals that love the company of other pigs; nonetheless, they will engage in cannibalism if all other options are void. Body language is extremely important for them in courting and mating rituals. They enjoy games and are natural explorers and have been known to also be keen problem solvers. And contrary to popular opinion, they are quite clean animals who are meticulous about their environments. They are averse to travel, preferring to cuddle with their mates and nestle. In terms of their interaction with human animals, it has further been noted that pigs develop particularly strong bonds with the humans that raise them and adore being scratched on the belly ([13], pp. 206-08). It is not clear that pig-behavior reeks of anything particularly illicit. For Douglas, however, the lure of "nice pigs" is exploded immediately when clear distinctions need to be drawn between the world of the sacred and the profane. In her reappraisal of Leviticus, she notes that pigs have always posed an intrinsic classificatory impasse: unlike "licit" livestock (cattle, sheep, goats, etc.), pigs have neither cloven hooves nor chew on their cud. The pig, for Douglas, "defies the classification of ungulates" upon which all norms of food propriety are erected; moreover, it eats carrion and also pollutes as it is farmed as food (and prime pork) by non-Israelites. Porkophobia is the product of "stern" and "tragic" religions ([12], p. 22; [14], p. 79). Abject and abjectified because of its liminality, the pig must be Haram, for no good can come of that which is genetically of two states, of two worlds, and of two valences. The pig collapses the fundamental binary structure of Islam and by extension pork is a critical riposte against the fundamental distinction between good and evil and its derivatives.

Contemporary Islam may find itself seized by new swine-related fears, as recent science has unearthed evidence that inaugurates a new chapter in the history of the pig's liminality. Humans and pigs share roughly $94 \%$ of their DNA. The porcophobia found in Halal is actually an interdiction against our distant relatives. In South Korea, pig hearts have already been successfully transplanted into monkeys, and pig skin and pig valves have already been used in human cardiac operations. Xenotransplantation between pigs and humans will, moreover, soon be a staple of contemporary medicine [15]. The genetic modification of pigs could also have immense implications on human and environmental well-being. While the Koran predates contemporary advances in medicine, many 
Muslim doctors remain deeply uncomfortable about organ-transplant's Haram status. Some stipulate that transplants are harmful to the donor while others deem the dead human body to have the same illicit quality of carrion ([16], p. 246). One can only imagine the ethical and religious impasses that pig xenotransplantation will present.

\section{The Slaughter: Of Religious Rights and Animal Cruelty}

The interdiction is the point of origin for a complex "pathway of authenticity" and ritual purity that spans from the proper methods of livestock breeding to the meat marketplace. This is a concrete and psychic pathway which resonates with material anxieties and a myriad of representations and imaginaries. The animal's life, from its birth to its ritual slaughter, is controlled through a series of agro-religious strategies that progressively sacralize the animal as it develops. Halal livestock is never free to fraternize with animals of the non-Halal farm. It cannot consume filth. It may not be enhanced through biotechnological products or processes wherein the risk of Haram is ever-present. Moreover, as Karijn Bonne and Wim Werbeke remark, in this important "Halal control point," the animal becomes fit for consumption if it has been "nearly starved to death during three to 40 days and then fed a natural vegetarian diet" ([17], p. 40). The more a Halal farm conforms to the standards of quality control and has its reputation validated by consumers and mullahs alike, the more likely it is to command a greater share in the global Halal supply chain.

Malaysia, the West Midlands of England, and the American state of Illinois, have all been identified as existing or up and coming "global Halal hubs". These new hubs are also implicated in a refashioning of Islam designed to placate the rancor of its perennial critics. Islam has been reproached for being, amongst other things, a retrograde religion, which has been unable to recalibrate itself to the political and social demands of hyper-modernity. It has been assailed for remaining an anthropocentric religion that persists treating the animal and the natural as raw materials to be manipulated on the road to redemption. Following from this, it has been at pains to seduce a new generation of Muslims whose commitments to Allah are matched by their commitments to the environment. Organic eco-Halal has thus burgeoned as a new means of "greening Islam". Eco-Islam farms exert the necessary quality control to remain Tayyib ("good"). They also position themselves in the new discursive terrain of contemporary political ecologies. However, for all of their claims to organic holism and "animal-friendly" policy, the next "Halal check point" still scandalizes and divides liberal pluralists, ecologists, and animal-rights activists alike: the slaughter.

For Baudrillard the industrialization of animal slaughter, synchronous with the advent stunning, captive bolts, and pithing, corresponds to the progressive animalization of man: "The trajectory animals have followed, from divine sacrifice to dog cemeteries with atmospheric music, from sacred defiance to ecological sentimentality, speaks loudly enough of the vulgarization of the status of man himself - it once again describes an unexpected reciprocity between the two... Those who used to sacrifice animals did not take them for beasts... They held them to be guilty: which was a way of honoring them" ([18], p. 134). The animal's "honor", exemplified in its status as vessel of communication with the transcendent and consecrated through its ritual sacralization, does not necessarily honor its welfare nor respect the rights that we may wish to grant it. Its rights, moreover, as the debates on zabiha (Halal ritual slaughter) reveal, potentially undermine the religious rights of the religious community that reproduces itself through the sacrifice. Liberal proceduralism descends into a 
double-bind where animal ethics collides directly with pleas for cultural and religious recognition. This collision is then imbricated in the larger nexus of green politics, national identity, multiculturalism, orientalist phobia, and the limits of tolerance. Here meat, citizenship, and the respect for animals and "others" find themselves uneasily enmeshed.

As a ritual sacrifice, zabiha must be conducted in accordance with strict protocols of cleanliness, instrumentation, invocation, and personnel. In its "classical" set of techniques, the slaughterer (or sacrificer) must be a mature Muslim of sane mind, body, and soul, and possess an intractable faith and knowledge of basic animal welfare. Depending on institutional demands within the umma, which are contingent on the criteria employed by the certifying actor, he may require a license from a recognized mullah. Moreover, depending on where the slaughter is conducted, he may also require a license by the state or its ministry of food and agriculture. The terrain or factory where the sacrifice is to be conducted must be meticulously purged of all things Haram. The animal must be kept unaware of what is to transpire and be calmly led to the sacrificial site. He must also not glimpse the knife that will be used to kill him until the moment of slaughter. As for the knife, it must be thoroughly cleansed, razor sharp, and preferably four times the size of the neck of the victim. The knife must sever with the sharpness of its blade and not by virtue of its weight or the force with which it is wielded. "Humane Halal knives" have recently been introduced into the Halal industry. One sold by the "Cornerstone Farms" promises strength, durability, and precise results [19]. Precision is the essence of the art of zabiha: in one swift motion, the slaughterman must sever the jugular vein, the esophagus, the trachea, and the cartoroid artery, while reciting Bismillah Allahu-Akbar (In the name of Allah) or Bismallah Rahman Rahim (In the name of Allah, most Gracious, most Compassionate). Dorsal cuts, decapitation, "sawing", and any severing of the spinal cord disqualify the sacrifice. Exsanguination should begin spontaneously and be profuse. Any signs of animal consciousness after the act also nullify the rite and render it Haram. Although some countries require pre-slaughter semi-stunning, stunning techniques, mechanical blades, and assembly-lines are generally frowned upon and are considered to push the slaughter to the precipice of mushbhoo.

Over the course of the last decade, the debate on calculus of the animal's pain in Halal food production has mobilized animal rights activists and also anti-Muslim xenophobes who conveniently instrumentalize "animal welfare" in the name of their political interests. Anti-Halal groups insist on the inherent cruelty of zabiha while Pro-Halal groups not only defend their practices as more humane, but also accuse the opposition of, amongst other things, advancing the vegetarian agenda, western decadence, culinary imperialism, and the juggernaut of Haram. In addition, arguments concerning the intrinsic value of animals of which status as "life" affords them with rights are rejected through strong appeals to a divinely mandated inter-species division of labor. Secular arguments against animal rights usually hinge on the proposition that as animals cannot be cognizant of their rights, they cannot enjoy their rights. The Islamic argument, on the other hand, dictates that humans and animals share differential responsibilities in the cosmos with the latter existing to serve the superior vocation of the former. According to Sahib Mustaqim Bleher, founder of the Islamic Party of Britain, "It is absurd that it should be considered a crime for humans to kill a sheep, but natural for a lion to do so. The problem stems from a misconception of the role of human life within the animal kingdom: a denial of purposeful creation within a clearly defined hierarchy degrades humans to the level of any other creature" [20]. For Bleher, the "Halal Method" differs from the "Western Method" in both its 
humanness and ontology. It fosters an intimate and religious relationship with the animal, which surpasses the coldness and cruelty of industrial farming. Yet, its humility appears tempered, dare one say, hypocritical in its metaphysical justification of the animal's pain. Contra radical greens and animal rights activists, it refuses to frame the rapport between humans and animals as one of equality or reciprocity. However, the relative stability of these arguments and actors is problematized when the discourse of animal rights encounters the science of animal feeling.

The slaughter of animals, sacrifical or industrial, through the Halal humane knife or the stun-gun and mechanical blade is a bloody affair typified by violence. And while Halal phobia may certainly be the product of anti-Muslim sentiment, it is also the result of the non-Muslim community's wincing (carnivores included) at the knife wielding, throat cutting, "exsanguinaters" of zabiha. Still, Halal phobia of this variety is particularly surprising insofar as non-Halal abattoirs, regardless of their employment of stunning technologies, are renowned for their bile and blood soaked environs, an abjection that not even the most hardened of recovering criminals can stomach. As Charles LeDuff, for instance, has noted of the American killing floor, the turn-around for slaughtermen is $100 \%$ and "five thousand quit and five thousand are hired every year. You hear people say, they don't kill pigs in the plant, they kill people" ([21], p. 85). Although veganism and vegetarianism are on the rise, the majority of the global world prefers to supplement its diet with meat-based protein and prefer not to know how their food was killed or if "it" suffered in the process. Anti-Halal science, intent on disproving the humanity of zabiha, and Halal-Science, intent on justifying it, are exceptions.

Electroencephalographic brainwave analysis (EEG) can now be employed by agricultural scientists to measure pre-slaughter and post-slaughter stress in livestock during zabiha, offering further evidence of how science can be recuperated by both religious and secular actors. In 2009, a team of New Zealand researchers led by T.J. Gibson and Craig Johnson concluded that stunning was a more humane method of slaughter than the "Halal method" and that the cut was unnecessarily cruel [22]. For Johnson, if the animal is concussed through stunning, signals corresponding to pain disappear whereas, in Halal slaughter, the animal experiences pain for nearly two minutes after the incision; claiming to have definitively settled the question Johnson further ballasted the "religious community" who remain adamant that animals do not experience pain during ritual sacrifice [23]. The Gibson and Johnson studies corroborated the evidence offered by the British Farm Animal Welfare Council (FAWC), which in its touted 2003 study "Welfare of Farmed Animals at Slaughter or Killing", rallied against the inhumanity of Halal practices noting that "such a drastic cut will inevitably trigger a barrage of sensory information to the brain in a sensible (conscious) animal. We are persuaded that such a massive injury would result in very significant pain and distress in the period before insensibility supervenes" ([24], p. 35) The FAWC decreed that all Halal slaughter conducted without pre or post-slaughter stunning be deemed illegal insofar as it was an affront to freedom from discomfort, freedom from pain injury or disease, and freedom from fear and distress to animals. PETA (People for the Ethical Treatment of Animals) has also released footage of animals girating madly and struggling to breathe after the cut [25].

Halal advocates scoffed and theycontinue to scoff at such attempts to, in their eyes, deploy EEG brain wave analysis and animal rights discourse to what they perceive to be Islamophobic ends. Nonetheless, against such ripostes, they too have taken to scientifically justifying Halal slaughter practices. Willhelm Schulz' 1979 study, entitled “Attempts to objectify pain and consciousness in conventional (captive bolt pistol stunning) and ritual (Islamic method of cutting with knife) methods of 
slaughtering sheep and calves" is incessantly invoked as the only proof needed to illustrates Halal's greater humanity. According to Schulz, Halal methods, unlike stunning, painlessly killed the animal within six seconds of the cut; during the first three seconds, the EEG and ECGs (electrocardiography scans) indicated no change in the animal while during the final three seconds, the animal was said to enter a state of deep-sleep unconscious ([26], pp. 62-63). Dr A. Majid Katme, of the Islamic Food Association, has also argued that Western stunning methods are at the heart of epidemics and can potentially spread mad cow disease in dissolving the brain tissue of the animal into its body [27].

The 2012 Imam's Conference was consecrated solely to the question of nutrition. The conference provided America's Islamic religious elite with yet another opportunity to vindicate the Halal method, offer rulings, and prove that science was always on the side of Islam. Citing the economic, social, and hygienic benefit's of Halal slaughter methods, the imams collectively tabled the "Islamic Ruling on the European Cut for the Slaughter of Cattle", where they, not surprisingly, argued that "Muslim scientists and veterinary experts confirm that the Sunnah method of slaughter employing a horizontal cut is the most humane, least painful, removes the most impure blood, and is the best way of slaughter..." [28]. Science ethics, of course, asks that we examine the value systems of scientists themselves and unearth how their moral and religious beliefs shape the criteria used in their research and the objectivity of their findings. Although the debate on the animal's pain and our capacity to empathize with it constitutes a perennial philosophical question (from Buddhism to Wittgenstein), in the case of Halal, it can function as a diversion. The objection to Halal's mode of slaughter may dissimulate a larger objection to Islam, an objection which itself transgresses a taboo in certain politically correct European circles. Indeed the Halal effect is less about animals than it is about the exercising of religious rights and the governance of food and immigrant populations.

The 1979 European Commission Convention for the Protection of Animals for Slaughter broadly calls for stunning to be the "accepted" means of animal slaughter, but, in Article 17, does allow for derogations from provisions in the case of religious ritual [29]. Iceland, Switzerland, Norway, and more recently Poland have all banned ritual slaughter in both its Kosher and Halal forms. The Netherlands, after a maelstrom of controversy, rejected the ban on ritual slaughter in June of 2012. In the UK, Anti-Halal protest is progressively applying more pressure on the British parliament. Slovenia will soon be voting on a similar bill. In keeping with the spirit of European freedom of conscience, autonomy, and liberal personhood, the majority of EU nations recognize animal rights, but make exceptions for the exercising of religious rights and religious freedoms. Careful not to resurrect the demons of Nazism in relation to Islamic populations and the Islamic diaspora, the majority of European nations have created mechanisms to manage and regulate Halal rather than outlaw it. Other global centers (the US, Australia) also allow for ritual slaughter while simultaneously making appeals to human animal practices. Predominately Muslim states, although in principle opposed to stunning, allow for some form of pre-stunning, which does not kill the animal prior to the cut, but desensitizes it (with Malayasia being one of the few to openly espouse the practice). Nonetheless, stunning is still considered by Halal orthodoxy to be wholly illicit.

The "religious exemption" applied to Halal immediately poses the questions of the legitimacy of cultural and religious rights and their limits. It also asks whether religion can be used as "an excuse" or a convenient means of suspending the law in the name of a wholly other authority. In addition, in a European context defined by the failure of managerial tactics of diversity and an ambivalent and 
Janus-faced regard towards Muslim immigrants that resonates with both misplaced paranoia and impertinent piety, Halal governance must move with caution, sensitivity, and a will to conciliation. Conversely, post-colonial anxieties and what Pascal Bruckner perspicaciously calls the "the tears of the white man", can be easily manipulated by Muslim religious actors (who often misrepresent their constituencies) in their quest to gain influence on both communitarian and national politics. Religious rights can further be instrumentalized by European nations in their attempts to maintain a liberal lump of good feeling and a politics of recognition that effaces their historic disavowal and invisibilisation of their Muslim communities. They can also be deployed by Halal communities as a means of politically coding ritual and food practices as a means of shunning the tyrannical hegemon of secular democracies and their diets. Following from this, the right to Halal can be, and without the least duplicity, posed paradoxically as an embodiment of Republican freedom as non-domination, a freedom from the culinary imperialism. However, Halal erects psychic, interpersonal, and spatial borders that can potentially be transfigured into forms of arbitrary domination themselves. Contemporary Republics and Liberal democracies, therefore, finds themselves uneasily charged with protecting the rights of religious groups and while assuring that all citizens remain equal before the law. The extension of such logics also naturally tends towards some form of meat libertarianism, where each autonomous citizen has the right to ingest whatever he wishes regardless of where it comes from or how it is killed. Yet, this may require that the law itself become pluralized to guarantee social and cultural pluralism thus standing to render citizens, at some level, unequal or susceptible to accommodation and special treatment.

Yet exemptions and suspensions of the law require "compelling arguments". And, as the calculus of pain between ritual slaughter and intensive industrial farming remains an open question, religious rights and freedom of religious expression often form the grounds for such arguments. In defining a "religious" exception, Halal policy circumscribes what "religion" is and unwittingly erects an argument concerning what types of religious sacrifices are legitimate (in this case, Halal and Kosher) and what types of religious authority justify the existence of ritual slaughter. Are newly formed religious "sects" and movements whose recently written prescriptions for ritual slaughter worthy of state and EU-based derogation? Are Islamic and Jewish slaughter practices more "hallowed" and commanding of the state's respect than those of, for instance, Satanic cults, neo-Dionysian organizations, or "sacred pacts" made between friends? Do non-food related religious sacrifices (Hinduism, Voodoo, African Paganisms, Santeria, etc.) ${ }^{3}$ count as exercises of religious freedom that necessitate similar policy measures and legal precedent? Do Halal and Kosher practices merit special attention because of the historical and political trajectories of their practitioners? Is the issue not really one of demographics, demand, and scale, rendering it a socio-economic question rather than a religious one? These questions illuminate the confusion regarding what kind of rights such religious rights really are. If zabiha constitutes a "general right", then it is not only demanding of a legal derogation, but indeed something which must be protected (not simply tolerated) by the law and potentially freed from the singularity of the ethnic, the identitarian, and the religious. If, on the other hand, it is the exercise

3 In the famous Church of Lukumi Babalu vs. the City of Hialeh Florida in 1993, the US Supreme Court did indeed decide that the state cannot regulate or intervene in ritual slaughter regardless of the intention of the sacrifice and the usages of the animal. This case, nonetheless, remains an exception rather than a rule and does not function as a constitutional precedent. It was concluded that religious sacrifice was a first amendment right. 
of a specific right (which it certainly appears to be), zabiha is placed outside of the scope of citizens who are equal before the law, and reconfigure the Halal effect as a "special interest" requiring particular modes of governmental intervention? [30]. The Halal state of exception, from a purely juridical perspective, thus places Islamic food practices outside of the secular state, but like secularism functions as a simultaneous means of "managing" Islam. More paradoxical is that the right to religious expression assumes the existence of a liberal subject whose subjectivity is recognized by his imbrication in a notion of individual autonomy that is born of his implication in the secular state. The Republican state ceases to be normative and the liberal state ceases to be neutral in according derogations to ritual slaughter; the Republic neither re-emboldens its commitments to secularism and citizenship, nor reaffirms the equality of all citizens before the law. And the liberal state's neutrality is called into question by its acknowledgement (and de facto support) of one set of religious practices over others.

Just as Chinese restaurants have been long stereotyped for serving dog and calling it chicken, Halal-phobes have historically conjured up gruesome tales of rabid imams and fundamentalists slaughtering livestock in their bathtubs. Conventional (and often base) wisdom would thus have it that the mass agglomeration of Muslims (and Halal consumers) in global centers would necessitate regulatory paradigms that respond to the "they're going to do it anyway" argument. With the rise of Halal slaughterhouses in the 1980s, the justification for national Halal committees, state dietary laws, and the intervention of various food and drug administrations in these enterprises has been defended in the name of food safety, hygiene, and consumer production. For instance, the Department of Law and Public Safety of New Jersey (USA) has created the famous "Halal Food Enforcement Group" who acting under "The Halal Food Consumer Protection Act (2000)", requires the New Jersey Division of Consumer Affairs to enforce the law ensuring that all food offered for sale or sold as Halal has been prepared according to the Halal dealers representations of his practices." [31]. The Halal Food Council of Europe was also registered in Brussels in 2010 as part of a campaign by both Islamic religious actors and European political actors to regulate, certify, and promote the values of Halal food. Beyond this, the Council also raises awareness about "doubtful ingredients" (granola, peanut butter, bagels, chips) [32]. It further maintains key partnerships with influential Halal associations in 15 nations including Brazil, Russia, Italy, and the US. Similar food commissions, meat associations, networks and councils have cropped up across the globe with varying degrees of state, local, and transnational legitimacy. Halal slaughterers and slaughterhouses are increasingly required to obtain state permits (on top of those already granted by religious leaders), register with governmental agencies, and oblige themselves to regular inspections by food police concerning their often still-hazy Halal standards. "Integration" into the governmental food apparatus creates a new field where secular and religious actors and technicians vie for positioning with a view to securing their respective political and economic interests. In forging ties with governmental and inter-governmental actors and agencies, the Halal industry gains "international" legitimacy, gains new paths of logistical and social entrée in the global economy, and naturalizes Halal and its religious orientation as viable products in the marketplace.

State interest in the recognition and regulation of Halal, however, is by no means of response to bloody bathrooms, and the fear of animal carcasses in alley trash bins. The ethical impasses presented by Halal, are, furthermore, not the unforeseen by-products of religious tolerance and the support of religious freedom. It would be a misnomer to assume that the implication of state-based secular actors 
in the "Halal religious field", was a neutral attempt to guarantee greater food security. The mullah and imam regulate the bodies and spirits of the members of the umma through the imperatives of Halal. Concurrently, the state, in surveying the Halal industry with a view to standardizing it, regulates Islam, places checks and balances on the power of Imams, "controls" food to advance and manage multiculturalism, and battles communatarianism through "integrating" Halal meat and those who produce and consume it. It also stands to profit.

Hence, as Florence Bergaud-Blacker observes, in France, "it is the economic potential of the Halal market which attracts the interest of the state. As far back as the 1980s, noticing the rapid development of Halal commerce, it envisaged a series of solutions for regulating the market which were intended to assure that the profits of the industry do not fall into the hands of Islamic groups that do not play the game of Republican integration" ([33], p. 6). Beyond religious rights, food security, and animal welfare, the key concern of the French government is to diffuse the possibility of black market Halal and its mafias, which could serve to fund anti-Republican Islamic groups. In diverting the streams of Halal profits, the French authorities weaken the strongholds of Islamic leaders and their influence and fracture the financial base of "Halal communtarianisms" whose authority is founded on religious revelation and not Republican reason. In legislating the Halal market through permits, slaughterhouse codes, and centralization, the French state does battle with a perceived radicalized Islam; And, as Philippe de Guénin of minister of agriculture remarked in 1995, "there will be no question of fundamentalists profiting from the abbatoirs" (Cited in [34], p. 4).

While France is certainly emblematic of a Halal Politics which pits the state against imams and butchers, the larger European context equally functions as a larger politico-religious field of meat, money, and minority rights. In 2002, the German Federal Constitutional Court over-turned previous 1995 legislation on mandatory electrical pre-stunning when Rüstem Altinküpe, a butcher, was forced to shut-down his basement slaughterhouse. He protested that the new ban on zabiha was a violation of his "basic rights". His arguments deliberately invoked Jewish Kosher practices and, thus, also tarried with German collective memory. Moreover, in a climate where German nationalist sentiments have increasingly revealed themselves to be Islamophobic, Muslim minorities have been likened, in both pejorative and journalistic discourse, as the New Jews. Altinküpe objected to not only the government's attempt to regulate how he kills his food, but also their double-standard in the case of Kosher products: "The Jews can practice the same form of animal slaughter as Muslims but I, as a Muslim cannot..." [35]. While Jews remained silent about the case and the comparisons, Halal lobbying groups progressively applied pressure resulting in the 2002 law, which acknowledged the insufficiency of the animal rights argument, and also, according to David Smith, proposed that permitting Halal slaughter, would "aid the integration of Muslims into German society"; Green advocates, in a paradoxical attack against right wing and reactionary animal protectionists, rethought their ecologies and came to also laud the decision, claiming that the ruling confines the ritual slaughtering to a very small group of people, and reduces racial and religious tensions in a multicultural society" ([36], pp. 113-14).

The Australian engagement with Halal treads a middle ground between German multiculturalism and French Republican "integrationism" and attempts to both regulate Halal practices and quash the more sordid articulations of Australian nationalism. Australia's relatively "new multiculturalism", one which has been born in synchrony with its recent developmental prosperity, has spawned both violent 
xenophobia and criticism of Halal's "ethnic enclaves". But it has also fostered a geopolitical awareness of the need for Australia to foster greater links with Arab nations through Halal trade and welcome those Malays, Bangladeshis, and Indonesians who frequent its universities en masse as future members of the Australian work force. Susan Rutland argues that banning "kosher or halal slaughtering would severely disadvantage two minority groups in Australia, which would go against the multicultural principles of equal rights and respect for difference" [37]. While Rutland is no doubt sincere in her concerns, when such rhetoric is inflected at the national level, Halal is a trade opportunity whose protection under "equal rights" equally works to insure future brain drain. Food politics is bound to the nation's quest for growing economic robustness - the social and religious question is an economic question. In 2006, Australia indeed hosted the Halal Trade Expo, an important event for Global Halal entrepreneurs and businesses. While the Australian business class reveled in the possibility of making 12 billion AUD by 2010 in the Halal trade, others were concerned about some of the expo's Islamic speakers whose agendas may certainly be economic, but also in line with Shariah, which dictates that Islam should be especially preached to those who live in non-Muslim countries [38]. In short, Halal policy and attitudes towards Halal, in global republics, liberal democracies, and commonwealths, have little to do with animal or religious rights. Rather, they are driven by concerns over political sovereignty, the management of new communities and enclaves, and, above all, various forms of local and transnational revenue.

\section{The "Certification": Of Trust and Credence}

The sacred is demanding. Its vitality depends on a certain imagined authenticity, which translates itself into various criteria concerning the proper care of the self and the care of the body. The sacred becomes untenable and impossible. As social beings, our selves and bodies mingle with others. Our sustenance is furthermore predicated upon our regular contact with and ingestion of the animal whose "natural" state must be purged of its abjection, disorder, and pollution through techniques of food safety and food purification. The sacred is an index of purity, however, its criteria can never be entirely fulfilled and its demands never met. The sacred does not speak. Rather, it is administered and spoken on behalf of by religious technicians who marshal its authority and set its standards.

The consumer or believer who cares (and certainly not all do) must trust that every trace of blood, pollutant, and Haram has been purged from the beast lest he fail the sacred. A space of "unknowing", Halal as ethos, attribute, and path to redemption, is embroiled in a game of credence and misrecognition which circulates in the chiasma between believer and butcher. And as the demand for authenticity remains infinitely demanding, politico-religious agents and masters of purity do battle with one another, each claiming to embody standards which are purer than their adversaries. The Halal meat market is also a market of spiritual authenticity, where dueling sacreds search to outbid one another in a web of bromides, self-righteous platitudes, and provocation. Hence, the most important Halal control point remains that of the certification, which may take the form of a stamp by a multinational certifying agency, a certificate signed by a local imam, or simply the butcher's word and local word of mouth.

The consumer as believer can never be sure of the intrinsic purity of the meat he consumes. The onus of authenticity thus falls on the Halal industry and its various apparatuses of certification, which tenaciously guard against the all too common instances of adulteration that have plagued the Muslim 
meat business and stirred concerns amongst those who have adopted the Halal lifestyle. Certification begins with the slaughter and its "ambience", an ambience that is defined by its liminality and the contingent nature of its exigencies. The consumer has no means of directly verifying the sanity and credentials of the slaughterman nor does he have the occasion to inspect the abattoir to assure that it is Haram free. But what are the frontiers and limits of Haram-free? Should the food be discounted as Haram if a non-Halal butcher selling sausage is next door or across the street? How does one go about certifying the Halal attributes of the slaughterhouse staff when they enter the abattoir from the illicit world if indeed Halal not be simply a concrete attribute but a quality of the soul (let alone a quality of what they may have mistakenly eaten for lunch prior to their shifts)? Do Halal foods become inherently corrupted if they are, as is usually the case, stocked next to or near bacon and pork in the meat aisle of a entirely Haram supermarket? These seemingly simple, yet highly complex issues reconfigure Halal as a "matter of degrees", but degrees, which are of vital importance in the passage through the void between the sacred and the profane. A liberal Halal attitude might dictate that each believer was free to be Halal in his own way and occupy a "degree" of the Halal spectrum as he saw fit. However, Islam has never been a typically "liberal" religion and straying from the "Halal course" has been historically known to come with consequences that problematize any moderate logic of freedom of Halal choice, selective Halal, holiday Halal, social Halal, or "sort of Halal".

"Global Sheikh", Shady Alsuleiman, exhorts the umma to ask "what does Halal mean in your life?" For Alsuleiman "following the Halal" is the path to happiness and the awakening from sleep. Noted for acerbic rhetoric that advocates an internal purge of Haram and its slaves from within the umma, he demands (or rather interpellates):

what category are you in... are you from amongst those who wants to obtain happiness, satisfaction, and contentment through the Halal and only the Halal or are you the other type that does not care if it is Halal or Haram. You don't care if its Halal or Haram as long as you possess it, as long as you acquire it, as long as you earn it—you don't think of that dollar that's in your pocket, or in your wallet, or in your bank, you don't think if that's through a Halal means or a Haram means. A Muslim lives his life only in according to the Halal and only acquires Halal and only eats Halal and only drinks Halal and only clothes himself in Halal and only lives in the Halal and only accepts the Halal because the Halal is the only thing that pleases Allah [39].

According to Alsuleiman, "the Halal" is not and cannot be a "matter of degrees" and regardless of what corner of the global world the believer finds him in, he must transform it into "the Halal" where he should reside. Halal is not a quality, but a place. But if Halal, at least on the level of meat, is a confidence game, one is never quite sure where one resides or to what degree. This obviously begs the question of the repercussions of eating Haram or even slightly Haram, particularly in a marketplace where such a prospect is not entirely avoidable. Depending on "degrees of belief", responses to the question range from the "practical" to the outlandish: upon eating Haram, one must, inter alia, throw up, swallow laxatives, repent, prepare for your prayers not to be answered for 40 days, ask merciful Allah for forgiveness, look forward to being tried on judgment day for what one could only call "food crime" (but God will be merciful in cases of Accidental Haram as it was unintended), understand that you may be damned and barred from the alcohol to be had in heaven (i.e., if you drink it here, you cannot drink it there), etc. Due diligence is a strict necessity. 
Industrial Halal plants have been, moreover, reproached for their usage of the "Halal track". Stereotypically associated with Belgian abattoirs, ${ }^{4}$ the Halal track is the continuous playing of prayers over an industrial conveyor belt where the slaughterman sacrifices en masse. The industrialization of Halal is notorious for its imperfect sacrifices, error, and easy slippage into Haram. The digitalization of Halal is alternately deemed forbidden or scorned as a cheap means of performing a ritual, which hitherto was embodied, visceral, and "authentic". As with Kosher slaughter, the logic underlying anti-digital-Halal invective rests upon the question of intentionality. In other words, if God commanded it, it must be done with intention, which machines and compact discs cannot possess. While the machine may be driven by a human and reproduce the human voice, its still mediates and thus dilutes, if not destroys, the non-mediated line of command(ment) coming from God to believer to believer's spirit to his hand that wields the knife. In Bonne and Verbeke's study of the control of the Halal supply chain, they note that, for Halal orthodoxy, "Neither saying a blessing at the beginning of the process nor the use of recordings is allowed" ([17], p. 42). Shaykh Siddiqi, secretary general of the International Muslim Association, has recently also called for a moratorium on KFC and questioned the legitimacy of its Halal certifier, the Halal Food Authority, for of its usage of taped prayers over rapid conveyor belts: "With machine-killing, they're not praying the prayer on each of the birds. In fact, when they are machine killing, they're not praying at all. They may just have a tape recording which defeats the whole purpose of Halal" (Cited in [40]). KFC, like those of many fast food chains that are introducing Halal menus, argues that Islam needs to modernize and embrace the advances in science, technology, and slaughter equipment. The Halal Food Authority have also solicited their own bodies of Muslim scholars and Halal food agencies to verify the rigor of their practices, but have also provoked a tense debate about Halal criteria and its malleability in a technological world [41]. The 2010 Agriculture and Horticulture Board/EBLX report, The Halal Meat Mar ket: Specialist Supply Chain Structures and Consumer Purchase and Consumption Profiles in England, further found that, in principle, although Halal can only be produced through tape and compact disc free slaughterhouses, only $20 \%$ of its sampled group of Muslim Halal consumers objected to sacrifices conducting via taped prayers ([42], p. 21). The growing acceptance of "digital slaughter" is yet another blow to orthodox Halal practices, which have already been seemingly warped by pre-stunning practices and machines. It also illustrates the descent of Halal into the mire of modern mechanical reproduction, simulacra, and rationalized efficiency. The Halal track challenges the grain of the voice and the tactility of the prayer's timbre. For some believers, it impoverishes the sacrifice, which should always be done "in person". The UK parliament is currently in the midst of series of debates concerning the need and desirability to label meat as stunned, pre-stunned, or un-stunned in supermarkets. To this, one can easily imagine the addition of yet another label for the Halal consumer: "live prayer"/“taped prayer".

Technology has also entered the domain of Halal certification (and come to serve the sacred) in other manners as well. Analytic techniques and meat scanning have proven indispensable in assuring that every drop of blood, blood plasma, pork based derivative, and pork-based preservative has been purged from the animal in its trajectory "from the farm to the fork". Authentication too is a matter of degrees, spanning from a backroom deal and handshake with a local mullah to the frontiers of the

4 Personal communication, "Mustapha," Butcher in Aubervilliers, France, "I don't eat meat when I go to Belgium or meat from Belgiums - they use cds and tapes for the sacrifice. Maybe the French are right, even their Islam is pauvre Belgique." December 5, 2012. 
burgeoning discipline of Halal science and technology. Halal modes of "pork and pork-based detection" include PCR-restriction fragment length polymorphism, polymerese chain reaction, enzyme assays, spectrometry, PCR sequencing, chromatography, gold nanoparticles, and the implementation of the "electric nose" (celebrated for its "e-sensing" and capacity to detect pig lard) [43]. Such technologies and scanning methods have been useful in resolving various Halal food scandals where Muslim associations or consumers have filed law suits against meat suppliers for product adulteration and the covert use of pork products and flavor enhancers. Although Halal authorities and certification agencies normally boast rosters of eminent meat scientists who certify with only the latest technologies, the internal workings of Halal science's role in meat authentication remains limited. According to Bergeaud-Blackler and Bernard, with the exception of Malaysia where Halal certification is not only state-controlled, but tied to norms developed in the Halal science labs of the Islamic University of Malaysia, the majority of global certifications are conducted on a purely voluntary basis by religious associations and with varying degrees of authorization and recognition by the state ([44], pp. 26-36). Imams in the USA, for instance, are often required to take food certification courses where modules on Halal purity are interspersed with workshops on "how to detect salmonella", but spectrometry and electric nose lessons are not included in the syllabus. The majority, however, rely on their own criteria and methods.

The imam's status may ultimately be purely symbolic and potentially rendered ever more tenuous with the advent of Halal science. In synchrony with Halal's penetration into the Occident, Halal science is no longer quarantined to the faculties of Health Studies in Malaysia, Kuwait, or Tunisia. The future of industrial global Halal is found in the "merger" between Halal science, Halal certification authorities and the Biotechnology conglomerates and pharmaceutical businesses of the "secular west". Already a subject of American, European, and Australian "market research", Halal standards will increasingly be shaped by biotech standards, which will serve to confirm the consumer's demand for "authenticity". In other words, the symbolic capital that circulates in the Halal imaginary is, in this case, subjected to the most stringent of material scientific scrutiny.

The recuperation of global Halal into the Western scientific post-modernity is the result of two dialectical processes that typify late neo-liberal capitalism: the absorption of the other's religious life world into the workings of multinational corporations and the simultaneous influence of religious organizations on the research and marketing agendas of these corporations. According to Johan Fischer, "The more Halal proliferates on a global scale, the more 'scientific' modes and methods of production, inspection and traceability become essential for producers, traders and consumers... Producers and distributors need to develop new processes and to refine existing ones, in order to live up to 'scientific' standards" ([45], p. 831). Fischer's wrapping of quotes around the word 'scientific' is far from arbitrary. Rather it points to the respective Halalization of science and scientization of Halal; deep within Halal biotech is another site of contention where science threatens to "de-spiritualize" Halal and Halal strains to "convert" science. Golden nanoparticles and electric noses may not work for the imam, but against him. But, the more nuanced imam may argue that these emerging technologies offer fundamental proof of how science is not antagonistic towards religion, but its greatest realization. Indeed, here there is perhaps no contradiction between the spirit of the Enlightenment and religion. On the contrary, science can be understood as not only God's work, but wielded to serve his ends. 
Nonetheless, Halal is not necessarily always a scientific or a religious affair. On the contrary, the religious dimensions of Halal can collude with the most profane of self-interests. Within the dark underbelly of late capitalism as Empire, within the shadows that trail its glorious transnational flows and fluxes, are roving mafias, cartels, and bandits, whose business is not delimited to the standard fare of guns, drugs, and prostitutes. Halal mafias profit from Haram and add a new dimension to the post-modern simulacra of fakes, cheap knock offs, and a market divested of all integrity. Although one might hesitate to go so far as to invoke the existence of a "meat trade", as Mustapha, our local butcher in Aubervilliers confirmed, many Halal associations have the audacity to call pork veal, an affront to not only to the moniker "Halal", but also an affront to the Halal consumer's taste and rudimentary capacity to distinguish between meats. He further noted that "it was not uncommon to find local imams who can easily be paid off to sign phony certificates of Halal authentication. Halal stickers can be easily fabricated at local office supply stores, Halal posters easily obtained, Halal light-displays purchased on Amazon.com, and in the most onerous of practices, meat suppliers and butchers can simply write Halal on their products and windows with everything from homemade stamps to magic markers" [46]. Yet another butcher in Saint Denis, "Hakim", openly confessed to me that he couldn't verify if the meat he sold was Halal or not, and frankly, this did not concern him: "people just want to see the word Halal on everything...that's enough for them, they really don't care either" [47]. One can only imagine the fiasco that would be unleashed when the consumer, in all good intentions, exclaims, "but it tastes like pork."

The ancient term Halal is, of course, not trademarked and many butchers, now pressured by rapidly expanding consumer bases and heightened inter-butcher competition, do not have the luxury of verifying whether their meat, stamped Halal, is really what it says it is. Halal certification agencies, however, virulently guard the sanctity and circulation of their trademarks. Yet, here again, authenticity is reduced to a sign, its reputation, and its "credence". It was a 2002 article in L'express, entitled "Islam's Money", that "broke" the story in France and confirmed suspicions that had been mounting since the late-90s;

Under the cover of moral obligations, this market is gangrened by money-making schemes. Who profits from the trafficking?...the faithful? Distanced from the noble combat of safeguarding souls... an all the more juicy market has been spreading itself little by little over the last 3 years for all kinds of alimentation labeled Halal: "a veritable mafia," "a racket," "exploited consumers:" for once, imams, mosque rectors, religious leaders, local butchers, and meat wholesalers are all in agreement. The object of their indignation - the fraud which gangrenes the French market of sacrificed meat according to the Islamic rite, called Halal. However, the rules are precise; only a Muslim sacrificer may... [48]. ${ }^{5}$

Despite its religious iconicity and status as an index of faith, Halal, like the logic of late capitalism, is typified by cynical reason - on the part of both the producer (who knows it's not Halal, but sells it anyway) and the consumer (who knows it's not Halal, but eats it anyway). Authenticity and the safeguarded souls are fetishes that reproduce themselves on the level of appearances or, in this case, Halal stickers. In this regard, global Halal is radically post-modern a religiosity embedded in a field of

Since the 2002 piece, Halal has become a beloved subject of French investigative journalism and a plethora of articles, special television reports, and dossiers have been consecrated to unmasking Halal. 
consumption, profit, and cartels, a religiosity whose claim to depth and soul sanctification is the by-product of the trust or feigned belief in the verity of surfaces.

"Pork scandals" proliferate across the globe, buoyed most notably by the internationalism of meat commerce, where one shipment of illicit or rebranded meat can spread Haram to diverse sections of the umma. The most recent of these, one which indeed corroborates the observations of Mustapha, concerns the 2011 Orion Cold Storage Company scandal in Cape Town, South Africa; as reported by Halal Media, it was discovered that the storage company was relabeling pork from Belgium and Ireland, Kangaroo meat from Australia, and Buffalo meat from India, as Halal chicken and veal, this being only the tip of the iceberg of a potentially much larger scandal of haramisation [49]. Orion Cold Storage's practices would be condemned by the Muslim Judicial Council, their principle certifier, who were equally quick to engage in a massive quality control initiative to redeem their good name. As for the Orion company, they accused rival meat distributors of sabotage, extortion, and blackmail, and signaled the existence of a conspiracy to sully their own Halal reputation. The director of Orion has also since become the target of death threats [50]. Besides transforming the Global Halal into an episode of the Sopranos, the scandal produced doubts as to the very viability of a Halal industry, thus prompting one local Cape Town newspaper to simply surmise that "The Halal assurance of slaughtering one's own meat, or buying from a known source can never be replaced by procedures and a logo. Until Muslims acknowledge that reality, controversies will continue" [51].

Imams and religious leaders fare no better in these currents of "gangrenization". Their authority and charisma have been repeatedly undermined by various Islamic theologians, self proclaimed sheiks, and Halal experts who create ad hoc certification organizations with the intention of monopolizing authorization, extorting butchers, and demanding a fee for the display of their logos. Amongst the most salient example of religious leaders "going Haram" emerged in England in 2011 with the Halal Monitoring Committee Scandal (also dubbed the Halal Monitoring Cartel Scandal). Drawing on interviews with butcher Ahmed Pervez of Medina Poutry in Halifax, a 2011 BBC report contended that religious leaders of the Halal Monitoring Committee (HMC), in fact knew nothing about the Halal industry and posed a danger for its integrity and future. Whereas the majority of Halal consumers took "Halal at its word", the creation of the HMC (like many local Halal authorities) was intended to establish a new mechanism of checks and balances against Halal corruption. However, this would come at a price as HMC leaders called on butchers and slaughterhouses "to pay a fee and display the HMC logo"; for Pervez, who refused to pay the HMC 300 pounds to brandish their logo, the committee qua cartel are, in fact, a group of "people set up by themselves, unannounced and uninvited, and really harming the Halal industry...they're nothing but scum, and people believe them because they appear to be Islamically dressed and Islamically knowlegable, but when it comes to Halal they have no authority." Yet another UK butcher Ayab Mehboob, simply claimed "I am selling Halal, why should I pay them [52]? Halal, once a "credence industry", has fallen prey to monitoring organizations that, capitalizing on the consumer's never-ending quest for authenticity, profit from branding "the real thing" and tarnishing the reputations of those who refuse to pay for their logos. However, following Pervez and Mehboob, why should an ad hoc group of imams organized in a committee have a monopoly on Halal — why is their "halal authority" more legitimate than that of the local butcher himself? Religious leaders once again seize spiritual capital, which only they can arbitrate, transmit, and negotiate. In the process, they also seize the real capital of the community of believers and assure 
that the "popular" Halal of the butcher is quashed under the weight of institutional religious force (albeit potentially " $a d$ hoc"). Halal reposes the ancient politico-religious question of the foundation of foundations, the authority of authority, and the check and balances needed on checks and balances. In this regard, it always remains unverifiable.

With a view to defiantly proving their absolute Halal status and again distinguishing themselves from the more unsavory and corrupted elements of the umma (and also their competitors), certification agencies have been forced to prove their ferocious religiosity and demonstrate their Halal rigor. And the more rigorous the certification agency, the more rigorous the butcher, and the more rigorous the consumer, etc. Your particular brand of Halal is transformed into a reflection of the depths of your belief. You brand is a measure of faith. As Kepel observes, amongst the most draconian of certification agencies is the French agency (qua movement) AVS, innocuously named $\grave{A}$ votre service (At your service). AVS' meat is marked by its intractability and, confident of the strictness of its "meat orthodoxy", it claims, without hesitation, that its products are 100\% Halal ([5], pp. 80-81). Founded in 1991 by a converted Jew well-versed in Kosher practices, Bergeaud-Blackler and Bruno also note that, AVS is typical of a second-generation Halal agency; AVS is hostile to stunning, draws its legitimacy from radical transparence and defiance and remains faithful to the visual modes of certification which harken back to the most ancient modes of Kosher verification ([42], p. 45). However, AVS' rising Halal hegemony and absolutism (in France and also, more recently, in Europe) is dependent not simply on strict certification methods, but rather on the elaborate construction of an AVS mythos which has developed in synchrony with the malaise of second-generation Arabs - a generation disabused of the myth of Republican integration and disconnected from the narratives of the trente-glorieuses that defined their parents and grand-parents, many of who themselves toiled in France's slaughterhouses and changed their names from Mouloud to Henri or René. Unlike their forebearers who willingly embraced the Republican promise at the expense of their primordial roots, their children and children's children search for modes of religious rigor, orthodoxy, and belonging, that fill in the void of citizenship and offer an alternative to a Republic that did not necessarily embrace them, that rendered them invisible in their own nation. In a more pronounced sense, in refusing the Republic, this generation proclaims its right to be what it was before the trials and failure of French integration: Arab, Muslim, and Halal. Narratives of citizenship and its waning are melded into meat.

Solidifying the umma means re-erecting and re-entrenching its borders. Mustapha's butcher shop proudly sells only AVS meat. On his wall, one finds the gold and purple plaque certifying his products and outside his shop is perched a double-sided meter tall AVS poster that eclipses the façade of the business itself. Mustapha confirmed that he could only trust AVS and that he held suspect his non-AVS butcher competitors. Upon asking, how one becomes a "member", of AVS he mentioned a rather informal test conducted by the organization to confirm that those who sold its products were practicing Muslims well-versed in their prayers. AVS does not allow its products to be sold by kafirs, although it welcomes their business. Mustapha is, moreover, subject to random inspections by AVS agents who search his shop to make sure that he is not selling any non-AVS products which, albeit potentially marked Halal, may not be $100 \%$ and thus, obviously Haram. AVS sustains itself on taxes levied upon its meats. As for certification, plastic tags, whose color changes on a weekly basis, are added to the products to confirm that they are AVS and butchers are invited to verify the weekly color. 
AVS' celebrated website and portal for all things 100\% Halal offers further testimony to its exacting standards; besides general information about the agency, it includes timely analyses of the latest in French meat laws, juridical and religious information about Halal, and is also replete with blacklists, revelations of trademark infringement, and an archive of past and present adherents to the agency. The log of résilations and fraude, updated regularly, "outs" those who have swayed from the AVS way and those who falsely claim to be amongst its members. The Grill House of Saint-Denis recently had its AVS contract revoked for apparently selling non-AVS meat products [53]. Silver Sushi, also of Saint-Denis, was accused of unauthorized usage of the AVS logo [54]. The Falguiére butcher shop in Paris has also been reprimanded for continuing to use the AVS logo after the dissolution of its AVS contract [55]. The list goes on. It is, of course, perfectly reasonable for any corporation to condemn copyright fraud and take steps to eliminate trademark infringements. Yet, in the case, of AVS, its "agents" and "verifiers" are authenticating much more than their meat products. Indeed, they have emerged as the progenitors of the community within the community $-100 \%$ Halal.

In December of 2012, AVS suspended its longstanding partnership with France's largest and arguably most prominent industrial Halal distributor, Isla Délice. In doing so, it solidified its reputation as radical Halal and assumed its desired role as the founder of an intransigent movement that would refuse commercialization and entrée into the Halal doxa in the name of purity. In short, AVS refused to sell out, a refusal that was born of an equally intransigent vision of Halal integrity. Isla Délice, a supposedly "Israeli Enterprise" with one Jean-Daniel Hertzog at its helm, has come under fire for being Zionist, selling Israeli products as Halal, and being, furthermore, housed by the umbrella organization of Zaphir, which in 2000 was forced to pay a fine of 2286 Euros to the municipality of Nanterre for Halal falsification [56]. Affiliated with the l'Association Rituelle de la Grande Mosquée de Lyon, Isla found itself obliged to «prove its Halal» and its partnership with AVS was repeatedly presented as evidence of its authenticity. Isla also polarized many consumers with its 2010 publicity campaign, "Isla delice-fierement Halal" which pastiched the iconic head of the French Vache qui rit, and thus subtextually cast Isla as a doyen of French Halal and French Islam, the Halal of the second generation born in France. In the midst of these inversions, accusations, and transgressions, Halal consumers also began steadily campaigning for Halal certification agencies that were $100 \%$ Muslim owned, operated, and run. This, for them, would guarantee that their meats were unadulterated and their profits not diverted into worlds and causes that were deemed less than savory (rumours continue to abound concerning Isla profits being diverted to Israel and other anti-Palestinian entities). In 2010, yet another "Isla scandal" surfaced: Isla was not only an "Israeli Organization", but was adulterating its products with pork whose key shareholder was Simone Veil, former French Minister of Health and Honorary President of the Foundation for Memory of the Shaoh. AVS, still Isla's certifier, also came under attack [57]. A grassroots cyber-movement, calling for the total boycott of all Isla products and their vendors, immediately emerged, and further divided the Halal community. Fethallah Otmani, AVS' press secretary and one man public relations firm, rapidly issued a communiqué to clarified AVS' involvement with Isla: he cried out against defamation, rejected the charges, and insisted on AVS as the sole arbiter and certifier of Isla's products. In addition, Otmani insisted that boycotts against Zionists should not be confounded with business with Jewish partners, but, should it be confirmed that Isla has Zionist tendencies, AVS would halt all collaboration [58]. On January 4, 2013, AVS announced that its break with Isla and Zaphir was caused by the latter's decision to obtain its 
turkey from CELVIA, which employed pre-slaughter animal stunning and did not "contain" the animal, obvious infractions against its strict Halal code and an anomaly in light of the 2012 French law which legalized non-stunning sacrifice with containing [59]. Other commentators, however, have insisted that the rupture is another necessary step in "taking back Halal". According to Katibîn, a popular conservative Islamic blog, the Isla affair implores the umma to ask "how one could believe that the products of corporation run by non-Muslims could really be Halal? They did not believe in the Koran, so how can we believe in the moral dimension of the ritual slaughter..." [60]? For Al-Kanz.org, the "cataclysm" of the Isla/Halal separation will have explicit ideological consequences and serve to fracture already delicate Jewish-Muslim relations; "Isla Délice is leaving AVS precisely at the moment when the Hebrew State kills and destroys Gaza. This divorce will be expensive for them, as the consumer confidence in AVS immunized the brand against criticisms of sympathy for the oppressors of Palestine" [61]. Asidcom.org has gone so far as to stipulate that Isla has been covertly using post-stunning techniques for over 14 years, using AVS as a mere "cover" for its practices (which AVS was entirely aware of...) [62]. In this dense web of authenticity, complicity, and rumor, meat is where the moral and the geopolitical merge. As for Isla, it is currently preparing itself for the aftershocks, which, in the world of French Halal, will be significant.

AVS' rise and increasing mediatization is due, in part, to its implication in such scandals and conspiracies, but also bolstered by the "crossover" success of Otmani whose status as preeminent Halal authority has moved beyond the world of meat certification and has been recognized by both the popular press and the academic conference circuit; a recent international conference on Halal at the University of Quebec in Montreal [63], where Otmani was amongst the speakers, has also drawn the attention of Canadian Islam Watch groups who claim that the event was a quasi-reunion of the Muslim Brotherhood whose end was ultimately to apply "pressure to introduce Halal into the Occident in order to impose the rules of Sharia and oblige everyone to pay for certification" [64]. Otmani and AVS are also suspected of having maintained previous ties with the Brotherhood [64]. Born in 1977, Otmani, studied accounting at the University of Lyon, and joined AVS in 2001 when he also became public relations officer for the Union of Young Muslims. Critical of laïcité for its "muzzling" of religions, he openly advocates the creation of Muslim institutions in France for the training of imams. And troubled by the lack of agreement on what constitutes Halal, he has avowed himself to tracking down "those who cheat" [65]. In synchrony with AVS, Otmani has labored to erect and defend the quintessential standards and protocol for what is and what is not Halal, while simultaneously straining to calibrate them to the demands of the European and Global food and culture industries. But, as with all things Halal, when Otmani talks about meat, he is talking about his vision of the umma to come, a community stripped of cheaters.

His 2010 volume, co-written with Mostafa Brahami and published by Tawhid and AVS press, Le marché du Halal: entre references re ligieuses \& contraintes industrielles, functions as both a Halal manifesto and hagiographic ode to the glory of AVS. Reiterating that the priority of Halal production and consummation is to please God, Otmani argues for AVS' success in both the transcendent and material spheres ([66], p. 206) Tractability, fidelity, the rejection of all doubt, exigency, and scruples function as the refrains of the text, where Halal is presented as neither a simple industry nor as "our food". Rather, Halal is a revelation, a moral toning up that ontologically transforms the believer as consumer: "in consuming a creature, the Muslim is reminded that he depends entirely on the Creator, 
that he strains to obey his principles in every act of his life. When he takes an animal to nourish himself, the Muslim knows that he is part of the creation, and that he depends on what God has placed at his disposition" ([66], p. 9). Eating meat, for the believer, is not an affair of sustenance. Rather, meat is a conduit to the sacred, or rather a vessel through which the consumer is plunged into the realization that he partakes of and is of the transcendent, in a relationship of radical dependence and willingly subjugated by impossible principles of perfection. Otmani's Halal is politico-phenomenological, "a question that troubles, because it interpellates our conscience", because it "interrogates our consumer societies", and "poses the question of the industrial rhythms of inhumane slaughter, incompatible with the notion of God..." ([66], p. 10). Yet, at the heart of this prise de conscience is also Otmani's equally intractable desire to create the ultimate "norm", and in the process, banish "stunners", rival imams, and Salafist detractors who question its integrity ([5], pp. 98-103; [67]). Halal certification, and its bodily and spiritual stakes, emerges not only as a war against Haram, but also a war for the conscience of the umma waged between religious factions and meat producers. Converting a believer to your "brand" is to also convert the believer to your brand of Islam. Halal criteria is a means of cleansing global Islam and solidifying spiritual authority-binding the umma in meat. Hence, as Kepel argues, the coup de force of AVS consists, in effect, in closing the debate, disqualifying mundane and not good enough Muslims, hypocrites and liars, those who do not satisfy its draconian criterion-and to exercise an incontestable moral and religious leadership destined to transform itself into political and economic hegemony" ([5], p. 97). In naming itself the judge of the good-enough and the not good-enough, certification agencies like AVS are transformed into inquisitions leading a two tiered struggle against the Haram outside of Islam and the Haram within it. And indeed these tribunals and their inquisitors certainly inquire or faire une enquête as to what form global Islam should take. In defining the norms of Halal, they aspire to set the norms for the new Islam, to be the only norm. Redefining what constitutes Halal is but one step in the larger redefinition of a religion and its politics.

\section{The Dining Table, the Mall, the Hotel: Of Conviviality and Alienation}

The sharing of a meal has always been the site for various forms of communion. The nature of such communion is not delimited to the circulation of social energies, mutual feelings of warmth, and levity. The shared meal can also be a means of fortifying and articulating shared cultural, religious, and national identities which are reflected in the cuisine itself, the rules and etiquette of eating, and the ritual and symbolic context in which the meal is served (commemoration, cultic meals, holidays, festivals, etc.). Food binds. It also functions as a means of articulating, not only one's tastes, but one's belonging to a particular moral or political community and its values and collective memory. Refusal to accept the food of offered by another breaks the unspoken contract of reciprocity that resonates under the act of dining. It effectively breaks the micro-social cohesion that the meal, an actor, strains to effect. Following from thus, poorly prepared food can inspire feelings of shame and humiliation on the part of the host. The meal can instill greater fellow-feeling just as it can ostracize and alienate. These processes and protocol are placed in relief by Halal consumption practices where, in food courts and cafeterias across the globe, it is not uncommon to find the "Halal kids eating at the same table".

Comfortably "living in the Halal" can be a daunting task in secular global contexts where forms of religious coercion must not only be strictly separated from politics, but also from food and dining. Navigating the desert of Haram requires that the believer be vigilant. In order to preserve the integrity 
of his bodily, religious, and social hygiene, he must laboriously verify the "quality" of his environs, his social relations, and what he ingests. The global desert implicitly asks the believer to bend and places him in the center of an impasse where his faith collides with the ever-flowing carnival of Haram on display. Should he not wish to be seduced, he may find comfort in a "safe house", or ethno-religious enclave whose "quality" is guaranteed by the efforts and commerce of his fellow-believers. As Bryan Turner thus suggests

Piety tends to have a radical impact on the everyday world of believers by encouraging devotees to change their habits or in the language of modern sociology to transform their habitus or their dispositions or tastes towards the material world. In short, piety or pietization of the everyday world has these Schumpeter-like characteristics of combining new elements to create a religious habitus that stands in competition with other possible combinations in a competitive religious context. These new combinations are then defined as Orthodox standards by which the worth of a good Christian or good Muslim can be measured" ([68], p. 2).

Halal is one such combination, a pietization of body, space, and place that collides with secular habitus and its culinary cartographies. Large concentrations of Muslim diaspora, whether in French banlieues, global "Arab quarters", or other supposedly "ethnic pockets", have transformed themselves, by sheer virtue of their demographics, into Halal zones. Exacerbating the already ambivalent reception of Global Islam by the secular world, these spaces also distinguish themselves by fostering a commercial and social landscape where the pervasiveness of Halal is often mistakenly perceived as code for non-secular forms of communitarianism that collapse the multicultural dream of the liberal Occident. On the surface then, it appears that one combination sets itself off from another.

When in the multicultural world "outside", a world of radical mixity, the believer must employ a series of technologies to guard the rigor of the "combination". According to Kamaludeen Mohamed Nasir and Alexius A. Pereira, he might employ a strategy of "defensive dining", where "defensive does not mean trying to exclude oneself from perceived danger or contamination," but is rather indicative of "a strategy utilized by individuals to maintain purity in an impure setting" ([69], p. 66; [70]). Drawing on fieldwork conducted in Singapore, the authors map the defensive strategy of Malay Muslims in the predominately Chinese nation along the axes of three primary nodal points: authenticity, the Halaless of the environment (food courts, restaurants, fast food, etc.), and the deliberation that informs the choice of all-Halal or "mixed" dining. Defensive dining emerges as a "religious precautionary principle" of which proper implementation reflects the evolution of the believers "Halal consciousness" and faith. In the "uncertified world" of Singapore, the banner MUIS (The Majlis Ugama Islam Singapura - the Singaporean equivalent to AVS) functions as a beacon of Halal safety for the believer. His anxieties about the unscrupulous contamination of Haram are allayed by its appearance in the restaurant's window ([69], p. 67). However, faith in MUIS' intractability is also a gamble and many Halal consumers remain unconvinced of its supposed standards. As Nasir and Pereira reveal, some consumers need to be assured that the cuisine is not only Halal, but that it is also prepared only by Muslims insofar as the presence of non-Muslims presents the risk of external Haram being imported into the kitchen ([69], p. 68). When pushed to their limits, such logics raise the possibility of the certification of the cook or food-handler's consciousness, faith, and body, resulting in yet another paradigm of what one could call Halal governmentality. Of course, one need not apply for the job. But, if one does, he must be potentially prepared for a certifier to examine not only his resumé, 
but also his consciousness. The same governmentality is, furthermore, inflected onto the locale of Halal commerce.

The defensive diner measures inter alia, the proximity of the Halal food stand to the non-Halal food stand, the presence of alcohol and pork products in the food court, and the disposition of other diners and their plates. He is characterized primarily by his mixophobia, which, once again, runs contrary to the mixophilia that defines globalism's dominant ideology. For instance, some will not "place their hands on the table" when they dine "at an outlet that serves both Halal and non-Halal food" as "the rag that has been used to wipe the table as also been used to clean other tables [where there might be non-Halal food]" ([69], p. 69). Others feel the need to guard a "safe distance between friends/ colleagues/strangers eating non-Halal foods...if the non-Halal food were to come within too close a proximity, the Halal-ness of the Muslim's own food could be threatened by accidental spilling, splashing, and so on" ([69], p. 69). Nasir and Pereira take great pains to frame their arguments strictly in terms of food. However, the implications of keeping a "safe distance" are resolutely social in nature. Borders are not simply erected between plates and tables, but indeed between the people who sit at them. And if Halal is not just a standard for meat, but also an attribute of the soul, the borders in question here are also founded on a hierarchy of being wherein the ontological identification of "you are what you eat" is given new meaning. The demands of piety, its strictures, and combinations, when articulated with such veracity, problematize and function as implicit critiques of global appeals to heterological forms of cosmopolitan conviviality. They also add a series of amendments to the contract that girds the communion that is the shared meal or rather risk annulling that contract tout court through refusing to come to the table.

Olfactory training is equally important in the instantiation of these borders (again giving new meaning to clichés of "what's cooking, smells good" and "smells good in the kitchen," etc.). Amongst the sample interviewed by Nasir and Pereira, were also those who "reject dining at the same table as non-Muslims who are consuming pork or alcohol on the basis of smell," demanding that Halal and non-Halal food stalls in malls be separated to assure Halal air purity and also noting that condoning the smell of alcohol would be tantamount to condoning alcohol consumption ([69], p. 70). The quest for "air purity" and a world of smells purged of alcohol and pork odors also delimits two worlds, two ambiances, and two classes of people whose essences cannot be masked by mouthwash and cologne. These cases certainly point to Halal in extremis, but are, nevertheless, the raison d'être for the advent of Halal segregation in Singapore. One-hundred percent Halal food courts, Halal neighborhoods, and "all Halal environments" remain the preferred spaces of congregation and dining for many believers ([69], pp. 71-72). Defensive dining inevitably reconfigures the geography of global urban centers and casts a new map that no longer demarcates divisions between nation-states, but between zones of "safety" and mixity (which are often frequented out of necessity or through the conscious decision to "mix"). And even air can be divided. Nasir and Pereira contend that this particular configuration of global Halal does not promote exclusionary practices, but rather promotes "active participation" in multicultural everyday life ([69], p. 73; [71]). Yet "active participation" is conditional. It signifies co-frequentation or peaceful coexistence rather than conviviality and the transcendence of primordial identities. It is a being together in the public sphere that is shot through with lines of demarcation. While both the Halal and the Haram may both walk and waft through the same mall and indeed the same food court, the former will forever guard his "safe distance" from the 
latter. The true essence of cosmopolitanism is not the mere co-mingling of multiple communitarianisms and traditions, but rather the overcoming of prejudice and primordial identity in the name of a larger shared collective will.

Offering a corrective to Nasim and Pereira's disavowal of Halal's isolationist tendencies, Gabriele Marranci asks if defensive dining is not actually offensive (the real question, of course, being offensive to whom and why). "Halal cosmopolitans" like Masim and Pereira subtextually place the onus of conviviality on the non-Muslim who is invited to eat Halal in the name of the multicultural global ecumene. Marranci, rather, examines the realities of Halal reception amongst Singapore's Chinese majority and unearths a substrate of stereotypes, anxieties, and paranoia. Typified by its managerial diversity and historically uneasy attempts to "integrate" and "accommodate" its Malay Muslim populations (who remain within the nation, but separate from it), Lee Kwan Yew's pleas for "less strict" Muslim dietary habits and a more fluid Halal reflect the stance of the Chinese majority, some of whom have also indicated their failed attempts at sharing food with Singaporean Malays ([72], p. 86). Eating habits thus constitute an important symbolic dimension in measurement of national integration. Indeed, the dining table and food court appear as sites where the nation is built, where the dialectic between ethno-religious territory and its deterritorialization in a secondary national identity is most forcefully articulated. To dine, whether defensively or offensively, is to enter into a dialogue with the state and its apparatuses of recognition. The demand for a less strict Halal by the Singaporean Chinese majority also reposes perennial questions concerning the necessary demands of the state on its citizens and their respective rations of compromise. How far should the Muslim consumer bend his beliefs and his Halal piety to gain recognition by the state as a "full citizen?" How far should the state go in advancing a toleration that acknowledges the demands of Halal while, simultaneously, guarding its commitments to secular modes of national cohesion? Who bears the burden? Who decides on the nature of the compromise? Who meets the other half-way and how?

For Marranci, defensive dining explodes these questions rather than facilitating their potential resolution. Beyond the political theoretical debates that circulate at the state level, "defensiveness" has also real implications on the playtime of young boys. Christian and Muslim kids who may be the best of mates at school, find themselves barred from playing together on religious grounds:

'Why do that? I mean, Mark (my son) can go and play at his Malay friend's home, but his friend cannot come to play at my home, even though my son would like to share the Playstation with him. The reason, you see, is his mother. She is worried about food. I told her that I know about halal food and I will be careful, but it seems there is nothing I can do. I felt very bad about it. It is as if they told us that we are dirty'... his is only one of several examples with very similar dynamics. There is a particular concern among many Malay mothers that their children may be exposed to non-Halal food or that their food may be otherwise contaminated, mainly by pork residues on objects or utensils ([72], p. 90). ${ }^{6}$

Being "careful" is not enough and the choice to allow your child to play at the home of a non-Muslim is also an issue of "credence", but one that lacks the proper certification methods. Defensive dining constitutes but one defense mechanism in a larger constellation of social taboo and, in this case, does little to encourage inter-religious fraternity let alone cosmopolitan conviviality. The

6 In a similar vein, in France, when Georges Orwell's Animal Farm is taught, some "Halal Mothers" refuse to let their children watch the film adaptation of the novel as it is replete with images of pigs (and Stalinist ones to say the least). 
fear of Haram may be one variant of larger middle-class anxieties, driven by mediatized modes of moral panic, concerning the "world out there". In the "world out there", your child may be invited to a play-date where the parents may not necessarily be of "good standing", where junk food and television abound, where plastic guns are de rigueur, and where a steady flow of alcohol and cursing are the norm, etc. In other words, Halal and Haram may also extend to the confused and confusing logic of what constitutes a "good family" in a world typified by unsavory excess.

When contextualized within the world of school children and adolescents, the decision of the Malay Muslim mothers to forbid their children from playing with possible "Haram" touches at the heart of a series of hitherto unexplored inter-generational ethical questions. The decision of the mother emerges from within the interstices of two competing obligations: on the one hand, she must maintain her piety and commitment to Halal. On the other hand, she is responsible for the social health, the well-being, and the growth of her child as a member of the Singaporean national community. The fact that obligation one trumps obligation two demonstrates the authority of the theological over the social and the political and reconfigures Halal as an alternative locus from which decisions concerning community, social relations, and kinship are made. Two ethical criteria collide, one decreed by the transcendent and one issued by social life and basic human needs (amongst them, friendship and camaraderie). In addition, one can only speculate as to the repercussions of such a decision on the child's developing perceptions of the "Haram world" and the future of global solidarity. This is already glimpsed in the development trajectory of the young Halal child to the Halal teenager; for instance, these cleavages become increasingly pronounced in high schools where, according to Marranci, appeals to mutual understanding and cultural sensitivity undermine themselves by advocating sectarian and exclusionary behaviour. According to one of his Chinese interviewees, "Grace",

We were on a school trip and we had to do everything by ourselves, like washing our clothes and cooking our food. We were mixed-Chinese, Malay and Indians. I recall how frustrated we felt when the Malay students insisted that we had to buy new forks and spoons which had to be used only by them. Some pointed out that the utensils could have been washed carefully, but the Malay students insisted that washing does not clean the contamination of non-Halal food. Because of their special diet, often the Malay girls used to eat together in a group isolated from the others; this was not really welcomed by the other members of the group. We felt that there was no need to eat separately, but we tolerated it. These kinds of things make you wonder how they can be part of any group other than their own ([72], p. 91).

In an act of conciliation, some Muslims openly advocate "Halal conversion" as a means of reviving fragmenting social bonds. Pleading for the Haram to eat Halal (and vice versa) results in an unspoken ultimatum wherein the possibility of communal life is dependent upon the shattering of historical inscribed systems of value. The cafeteria is the stage for a conflict between two world views and politico-religious dynamics wherein the common can only be forged through the cooptation of the other. In respecting one religious taboo, a series of other secular social taboos are violated. Hence, in the adult world, as Marranci further elaborates, such practices carry over to a host of other techniques that confound the quest for cosmopolitan forms of syncreticism and potentially inflict forms of moral and personal injury:

bringing one's own food to parties and dinners despite efforts to provide Halal or non-pork and alcohol-free products by the host; abstaining from food altogether; refusing, even in the case of the same gender, to shake 
hands for fear of contamination; refusing to drink from glasses at the homes of non-Muslims or requiring plastic disposable utensils ([72], p. 91).

The virtues of piety collapse the ordinary virtues embodied in secular forms of sociality and invert the rules of their etiquette, common decency, and politeness. Contracts are broken. Invitations refused. Hands not shaken and abjection projected onto non-Muslim friends and nature. From the perspective of "the Halal", the Haram is radically Othered. Class does play a role in the dining strategy with elites who discretely do what they can to remain Halal while being careful not to offend. For less educated Malay Muslims, the threat of contamination is imbricated within a constellation of race, ethnicity, and nation readily; threat of contamination is extended to entire populations of peoples, most specifically, Chinese "Satanic Pigs" ([72], pp. 92-93). For these lower class Malay Muslims, "Halal" is not simply a defensive strategy, but also a means of to coping with social alienation, a source of pride and dignity, and the totem of an imagined community. Food, race, and relations of political and class-based domination are thus fused in the assertions of Halal and Haram. Halal does the work that the nation cannot.

The opposition between the two poles is further complicated by debates concerning the supposed union of revealed religions that bind the "people of the book" (Ahl al-Kitab), a mutual accord which, according to some Imams, would not necessarily prevent the Malay Muslim boy from playing (or eating) at Mark's house. Chapter 3 of the Koran, "The Family of Imram" is replete with passages that not only sing of the great brotherhood of Muslims, Christians, Jews, and Sabians, but also their Abrahamic unity in the ONE whose most triumphant incarnation is Allah. While each may possess their own religion, cults, and rituals, their goodness will be judged by the same God ([11], pp. 40, 48, 52, 60). However, the Koran's tolerance to its fellow monotheisms certainly does not pave the way to total reconciliation or "inter-faith dialogue", but rather espouses the adoption of a polite and safe distance to those who do not explicitly submit to Allah. When it comes to feasting, however, the Koran does not appear to equivocate and in chapter 5, verse 5, one reads: "Today all good things have been made lawful for you. The food of the People of the Book is lawful for you as your food is lawful for them" ([11], p. 68). Verses of this sort have given cause to reflect on the stringency of Halal practices and not without the least bit of ecumenical confusion.

The Halal Advocates of America are quick to note that the lawfulness of the food of the people of the book, does not mean that a believer has carte blanche to patronize "secular grocery stores" and restaurants, regardless of the religious denomination of their owners or chefs. Nor should he assume that the meat produced in a predominately Christian or Jewish country is edible. For the Halal advocates, this would be to take things too far; the believer may eat the meat of a Christian or Jew if the said Christian or Jew has slaughtered it or verified that it has been slaughtered without stunning, mechanical interference, and with the prayer of Bismallah being properly recited. In other words, the people of the book may slaughter the animal, but only in observing Islamic food practices (which necessitates an obvious denouncement of their own religious commitments). The piece closes by confirming that if Muslims are to bring about change, they must stand united on such basic issues [73]. In its most hyperbolic form, such logic crystallizes in the slogan "For love of Jesus, I converted to Islam." But, as with all things Halal, consensus regarding the proper engagement with the other monotheisms is impossible to locate. 
A Nebraska Halal Association, Halal Transactions of Omaha has rendered its criteria more fluid, by effectively invoking a “don't ask, don't tell policy" about the meat of others. Equipped with its own board of technical and Sharia advisors [74] regarding the people of the book, it has concluded that, "If a Muslims hears a Christian or Jew invoking the names of other than Allah subhanahu wa ta'aala, he should not eat from that Dhabeehah. However, if he does not hear them, he should not ask about it either. We cannot force the People of the Book to invoke Allah's Name when slaughtering. Hence, their Dhabeehah is Halal even with out invocation" [75] my emphasis). The "liberalization" of Halal paradoxically appears to reaches its point of paroxysm in the criteria announced by IslamRevolution.org, a group of quasi-Salafists who long for the return of a "pure Islam" free of corruption by the West and false preachers. In a comparatively "loose" interpretation of Verse 5:5 IslamRevolution.org affirms that:

People of the book are Jewish and Christians. Jewish people have a sacrificial ritual almost identical to ours, and it makes perfect sense that their food is lawful for us. On the other hand, Christians do not have any ritual to sacrifice animals that evacuates blood effectively like in the Jewish or Islamic ritual. Nevertheless, their food is lawful for us according to the Quran, and it is God's mercy to make the religion easy for us...Muslims should preferably eat meat that has been sacrificed according to the Muslim ritual whenever it is possible. Lots of Muslims who live in the Western world do not always have that option; it is then possible for them to let the meat sit on a layer of salt (for example), which will absorb most of the remaining blood. By extension, Muslims can go to pretty much any restaurant in a Jewish of Christian society, and live a normal life. [76].

The God of IslamRevolution.org would, of course, prefer that Muslims eat meat that is properly slaughtered, however, in his infinite mercy, he is quite willing to adapt himself to globalization and Islam's modern transnational contours. However, "verification" for those who habit supposedly "Jewish or Christian societies" becomes plagued with uncertainties when the believer finds himself in the presence of, amongst others, "cultural Jews" in the USA, "catho-laïques" in France and much of Europe, not to mention those who might, on the surface, "appear" to be polytheists and pagans, but count themselves among the people of the book. Aware of the logistical challenges and potential embarrassment that may arise in demanding the "religious credentials" of every restaurant owner, shop-keeper, and food handler, Mufti Abdur-Rahman ibn Yusuf, in an article entitled: "Zabiha-Meat Madness," leans on the side of caution: Noting that one cannot assume that Canada, the US, or European countries are necessarily "Christian nations", he argues that:

When purchasing meat from a regular grocery store, it is generally impossible to learn whether the slaughterer was a Christian, Jew, Buddhist, Baha'i, atheist, or, for argument's sake, Muslim; and even if it is theoretically possible to find out, the informational costs and bureaucratic barriers are too prohibitive for it to be feasible. If we then make the venturesome assumption that the slaughterer is a Christian or a Jew, the adherence of these, especially the former, to the laws of slaughter laid down in their scriptures is tenuous, as a few moments' examination of practicing Christians and Jews will show... In general, we must be wary when confronting an issue in which uncertainty clouds the path to finding the sure ruling; we should err on the side of caution in such affairs... abstaining from something whose permissibility cannot be established is, with little or no exception, the best path to take" [77]. 
Nonetheless, with an apparently "Muslim" food vendor (and it is not clear what marks one as properly "Muslim" or not), no questions should be asked about the existence or stringency of his faith; a Muslim family in America recently consulted the IslamNewsRoom to ask if it was okay to patronize a McDonalds that was not in a "Muslim country", but owned by Muslims. The response: "Absolutely yes. If Muslims tell you they are offering you meat, you should not even question it. This is confirmed from the sunnah of the prophet, peace be upon him" [78]. The confusion that enshrouds Halal's borders and the concurrent vigilance that the believer must exercise towards the "combinations" of the Other (which he approaches with "defensive strategy" rather than in terms of a dialogical encounter) are the necessary consequences of globalization's own will to border dissolution. Yet the future of the Halal narrative does not terminate in a glorious post-national, post-ethnic, and certainly not, post-religious constellation. On the contrary, as IslamRevolution.org, makes clear, it concludes in the globalization of the border itself: "Islam will become the primary religion on earth in the near future. God willing, it is up to Muslims throughout the world to insist upon the fact that meat sacrificed according to Islamic ritual may become the norm, wherever there are enough Muslims to make it possible" [76].

The establishment of the norm also brings global Islam into contact with that other monotheism, one that does not necessarily have a clearly delineated "people" and certainly not a "book": late capitalism. Global Islam remains torn in its reception of and implication in hyper-modern societies of consumption. While American neo-conservatives have been anxious to homogenize global Islam as anti-American, anti-democratic, and anti-Occidental in its fundamental essence, these polemics betrays nostalgia for a tidy world of bi-polar conflict and pastiche the Schmittian dictum "tell me who your enemy is and I'll tell you who you are". Rather, global Islam and capitalism appear dialectically bound in a series of class-based appropriations and counter-appropriations, which reveal how fidelity to Halal's transcendent transhistoricism and market-based Halal futures are narrativized and negotiated. As Patrick Haenni observes, on one pole of the global umma, are those"new religious entrepreneurs who oppose the fatalistic universe and localism of traditional Islam with a 'market-friendly,' bourgeois, cosmopolitan, and pro-active religiosity, who seek to instantiate the spirit of capitalism within the umma...Market Islam is not the expression of the disinherited. It is situated in a bourgeois universe where piety, wealth, and cosmopolitanism become substitutes for ideals of social justice and the valorization of a frugal life associated with Traditional Islam" ([79], pp. 59-60). And for the bourgeois "Market Muslim", nothing crystallizes Global Halal's embrace of the new spirit of capitalism better than the Makkah Mall in Saudi Arabia.

Its food-court boasts an eclectic variety of Halal cuisine and includes the Italian restaurant Roma Way, the Mexican café, Tako Hut, and American fast-food outlets, such as KFC and Burger King. Home to the Body Shop, La Senza lingerie, Coach, and the Gap, one can also shop at New Yorker which "offers Young Fashion, jeans, sportswear, and streetwear, for a young trend conscious target group-supplemented by a wide range of accessories and underwear" [80]. Yet, trend consciousness has its limits, particularly when its purveyor is Paris Hilton. Her decision to open a boutique at the Makkah Mall, her fifth store in Saudi Arabia, has incited a maelstrom of debates on the shifting boundaries of Muslim consumption and its topography of the sacred and the profane. Vocation-less and arguably vapid, Ms. Hilton's career is epitomized by a series of deliberately orchestrated moments of self-shaming, scandal, and "Haramisation" that have prompted even third wave feminists like 
Camille Paglia to summarize her exploits as those of a "backstreet floozy", degrading the entire pro-sex wing of feminism. The opening of the Makkah Mall boutique is but one of Hilton's many controversial forays in the Gulf Region. In 2009, she angered residents of Dubai by posing for photos in a bikini, while simultaneously being trained in Islamic culture by a hired "cultural expert" [81]. She quickly made a conciliatory speech, professing her love for Middle Eastern culture, while simultaneously being warned that Westerners have been jailed for transgressing the rules. Her television show, "Paris Hilton BFF-Dubai" which sees Hilton "auditioning new best friends" premiered on MTV in April of 2011. It was deliberately made more Halal and Islam-friendly, eventually garnering the approval of the Prime Minister of the United Arab Emirates. This should come as no surprise - according to ArabianBusiness.com, "In 2008, it was reported Hilton was to lend her name to a set of towers in Dubai, as part of a $\$ 2 \mathrm{~m}$ three-year deal with an Abu Dhabi-based developer" [82]. Hilton's "bikini blasphemy" roughly coincided with Nicolas Sarkozy's decision to ban the burqa in France creating an immediate public clamor about the rights of both secular and religious nations to impose their dress codes on both local citizens and international tourists. The female body was again transformed into a battlefield and transformed into a screen upon which secular normativity and the respect for the other and her religious rights and customs were projected and ensnarled. A vulgar pragmatism took hold of many "hard secular Republicans" who cynically uttered amongst themselves, and without the least concern for appearing simple let alone impertinent, "well if Hilton can't wear her Bikini on a Dubai beach, then why should we then allow for veils and burqas-its not about religion, is just about fairness" [83].

While by no means iconic of the virtues of secular reason and democracy, Hilton's new Makkah store has been received as the West's ultimate affront to Islam in its holiest of cities. Those opposed to the store deem the chain's presence in Makkah to be signs of the cities "Disneyfication," an "atrocity" which tears apart "Islamic Heritage" [84]. The opening of Hilton's store further prompted a more general review of how much Haram can be permitted in the holy city, let alone exorcised by Halal strategies or Market Islam rationalizations (which, following Haenni, would lead to the seemingly awkard formulation: "I can buy the Paris Hilton handbag because of Allah's gifts and blessings..."). An American sheik, Omar Baloch, carefully assessed the situation with a Youtube polemic in November 2012. Rejecting those voices that claimed that Hilton's store was just about "business" and equally reproaching those Muslims who frequented Makkah's many Hardees and KFCs for zahiba Halal fast-food, Baloch argues that the infiltration of Western businesses into the Gulf Region was an infiltration of Western Culture, one which necessitates intense moral deliberation on the part of the believer; Paris Hilton, he remarks, is not simply a brand, a logo, or a celebrity, but a symbolic index of a certain set of values which are equally abhorred by many of America's own Christian populations. Baloch implores the scholars of Saudi Arabia to stand up against the hijacking of Islamic values by Paris Hilton and give back Makkah to the Muslim community. "This is not", the sheik continues, "a limit we are willing to cross...I know that Saudi Arabia has been sold-out...it shows that you [the Saudi Authorities] have no heart, have no boldness, that you are cowards, you don't have the audacity to hold up your values... don't blame Allah later on, twenty, thirty, forty years from now when things will be very, very bad...as they will be" [85]. Baloch's brief riposte prompted rage from counter-jihad alliances and Saudis alike, both indicating their varying degrees of unease with what they perceived to be Baloch's extremist and wahabist tendencies, and also illustrating Paris Hilton's 
power to polarize Europe and Saudi Arabia and the global umma. Hilton has not commented on the aftermath of the incident, nor her implication in the very, very bad future to come. One can only imagine that she is flattered by the attention, which her "less-Haram" competitors in Makkah, amongst them Gucci and Christian Dior, have yet to receive.

Room service at the Hilton Hotel in Makkah is strictly Halal or Vegetarian. Moreover, the proprietors of the establishment are keen to remind those interested in using its facilities that the hotel is a "Muslim-only Hotel" located in a "Muslim-only district". However, the Hiltons have yet to capitalize on the newest trend in luxury vacations: Halal tourism. Halal tourism is shot through with its own internal contradictions. On the one hand, it functions as a leisure industry promising the Muslim elites the purest forms of rest, repose, and recreation from within the folds of the global. On the other hand, such appeals to "pure leisure" are mobilized to rebuff the penetration of the global and "quarantine" certain beaches. In other words, while certainly a form of "religious tourism", it is not simply a question of organizing logistics for a pilgrimage to Mecca. Crescent Tours, promising "holidays with an Islamic ethos" [86], invites the Muslim leisure class to play with confidence in its many Halal Sun Beach Resorts and Spas. Based in Turkey, Crescent Tours'

Halal resorts and hotels only serve halal foods and there are separate pool, spa and leisure facilities for men and women. Cafés and restaurants serve non-alcoholic hot and soft drinks. There are private women only beach areas and also mixed beach areas for families with Islamic swimming dress code. There are also prayer facilities on site. Islamic Heritage tours are there to explore and discover history and culture of Islamic civilisation. All activities are geared towards maintaining the values and modesty of Muslims desirous of following the Quranic encouragement to travel throughout the earth to see God's signs and patterns everywhere [86].

In a curious inversion of Serge Gainsbourg's ode to sea, sex, and sun, these holidays are bastions of "sea, sun, and Halal". As for bikinis, women are given a choice: they are permitted to wear bikinis only in secluded quarters in front of their husbands. Should they decide to frequent a mixed-beach, the burquini, a highly practical and "global" piece of licra allows for Muslim women to no longer have to wait for the men to vacate the beach to take a swim [87]. Nonetheless, "ocular Haram" is not entirely averted insofar as a male patron of a Halal resort may find himself in a "room with a view"; during journalist, Nasreen Suleaman's visit to a Halal hotel, his panorama was one where, as he notes,

I could see women in bikinis. And if I could, then so could the male guests. But then, as the hotel manager, Livant, told me later: "We're not as conservative as the media like to make out. We let the women decide how much they want to show of themselves but we draw the line at men and women sharing a beach or swimming pool." To be fair, the women's beach is far enough away that men would get no more than a glimpse of a female body. And I later discovered there was the option for the kind of seclusion and dress that wouldn't compromise one's modesty in the slightest. Livant pointed at a young girl playing in the open-air pool with her father. "It is OK for young girls to swim in it but if she is 10 , or looks 10, she would not be allowed in." Instead, she would be directed, like me, to the women-only pool. Livant knocked on the thick wooden doors and stood out of sight as one of his female staff opened it and led me down, through a basement room with a gym and a relaxation area, to an outdoor pool safe from prying eyes [87].

The presence of such a male gaze (or "glimpse") in an otherwise all Halal visual field problematizes the inter-Muslim and intra-cultural politics of looking on a series of fronts: It makes it okay for 
Muslim men to "glimpse" Muslim women in bikinis, but bans Paris Hilton's bikini on the Dubai beach on the grounds that she might potentially corrupt her environs and the visual field with Haram and Western Decadence (unlike those Muslims in bikinis at the Halal Hotel). However, it moreover, affirms the legitimacy of Muslim male desire in relation to the bikini-clad Muslim female body (even the beach is "far enough way") while placing a bar on the Muslim male desire when its gaze is directed at Paris Hilton, who was not, incidentally, kindly directed to a women-only swimming pool or beach. Here Halal anxiety and male anxiety merge and Halal comes to function as a strategy to control and cordon off the female body. Again, Halal, even in its protocol of seeing, appears as a fluid construct, a matter of degrees, where there exist hazy choices and circumstances whose too forceful expression elicits the appearance of an equally mobile interdiction.

Ostensibly troubled by such haziness and, more importantly, by the presence of alcohol and scantily clad foreigners on "Muslim" beaches, certain radical Salafists in Egypt are calling for a more orthodox approach to Halal Tourism. And this approach is one which does not equivocate about the nature of the permissible and the illicit. Lacking in fossil fuel resources, the future of Egyptian economic stability and prosperity relies heavily on the dual movement of progressive decentralization and private entrepreneurship and tourism. While constituting only $1 \%$ of the world's tourism market, Egyptian beaches continue to function as an economic life-line for this nation in transition. The Al Nour party and the Muslim Brotherhood are cognizant of the stakes of Egyptian tourism and regardless of their respective conservatisms, have not chosen to implement Halal regulations on Egypt's beaches, hotels, and resorts. For Yassaer Al Bourhamy, vice-president of the Al-Da'waa Al-Salafiyyai, such concessions to the West, albeit made in the name of future national stability, threaten to roll back the very essence of Halal and the piety that characterizes the true core of Egypt's people. He dreams of "sinless vacations": "A five-star hotel with no alcohol, a beach for women-sisters-separated from men in a bay where the two sides can enjoy a vacation for a week without sins... The tourist doesn't have to swim with a bikini and harm our youth" [88]. Bourhamy's vision of Egypt's Halal future once again raises the question of the necessary causal link between bikinis, moral harm, and the corruption of youth. It has disconcerted and divided ministers and politicians of both moderate and extreme right factions who refuse to hang Egypt's future economic balance on the choice between Halal and Haram. From within this double-bind of religious piety and national prosperity, statues and ancient Egyptian monuments are also being "re-considered". For instance, at a 2011 Salafi rally in the Mediterranean port city of Alexandria, some "party loyalists covered up mermaid statues on a public fountain with cloth" [88]. However, the covering up of mermaids would have deep implications on the emblems of Egypt's polytheistic past, its statues of nude pharaohs, orgiastic demi-gods, and fertility goddesses. In response, Tarek Shallan, a prominent figure of al-Nour, observed that the pagan traces of ancient Egypt "will be put under a different light to focus on historical events...He also failed to explain whether hotel reception clerks will have to start demanding marriage certificates from couples checking in together" [88]. Halal may therefore potentially tamper with cultural heritage and "purify" the past with a new revisionist history (or risk creating an incoherent world where one finds covered up mermaids flanked by ithyphallic totems and buxom divinities). It may further morph into a type of "profiling" and which controls the movements and access of populations of Haram. Suffice it to say that the possible hegemony of the Halal orthodoxy over Egypt's tourism will have devastating effects on the nation's economic stability and those who work in its immense service sector, many of whom 
are themselves pious Egyptian Muslims. Compromises between economic necessity and the rigors of faith will have to be made.

\section{Halal Politique: From Steak Frites to Grec-Frites}

Market Islam is not simply the province of elites. In France, it also infects the tissue of socio-religious life in housing projects, "urban" zones, and inner cities often deemed "défavorisés". It thrives in nascent street cultures where the local vernacular is informed by a brew of religion, Rai and Rap. Hence, at the opposite end of the spectrum, we find the syncretic and "modernized" Islam of adolescents in the banlieue who fuse the imagined virility of Islam with hip-hop culture and create a dispositif of "street Islam" which melds the seemingly disparate universes of hip-hop consumption and indulgence (jewelry, cars, dreams of harems of groupies-this often coupled with anti-Semitism, misogyny, and homophobia) with a religiously militant or "consciousness-based" secondary-coding that responds to the position of second generation Muslims in France. The symbolic protest of hip-hop sub-culture, the hedonism of "market hip-hop", and Islam converge. As Jean-Paul Brighelli pejoratively notes, in such hybridized worlds, "Drink Coca-Cola and Death to Infidels are two equivalent slogans" ([89], p. 258).

However, the soft drink of choice for many young European believers is actually Mecca Cola whose motto is not "have a Coke and a smile", but "don't drink like an idiot, drink like an activist" and "not to be mixed with spirits". According to its founder, "in these times where Islamophobia is so intense, it became evident to us that if we wanted to preserve our identity, we would have to come up with a name that would federate us, unite us and unify our efforts on behalf of Islam. To drink Mecca-Cola is, for us, a concrete manifestation of our faith and of our solidarity on behalf of Islam and the Palestinian cause" [90]. Mecca Cola is recognized by the L'annuaire musulman in France, the reference guide for Haram and Halal in the Francophone community, and its UK distributer is none other than the National Halal Food Group. Mecca Cola, one variation of the logic of Halal, exemplifies a way of "staying home" and "unifying" in global deterritorialization. Nonetheless, the boundaries of such a mutating home are permeable and laid down in an often ad hoc manner.

In France and in the banlieues of Paris, these deterritorialized mutations have been received by many on the French right as signs of a larger annexation of French territory and the Republic itself. Hence, burgers and meat are readily identified as harbingers of the growing encroachment of political Islam on French Republican virtues. A Halal Big Mac is greeted as not a sign of religious tolerance within the food industry or food diversity, but rather as a threat to the national edifice. In a curious set of polemics, between 2010 and 2012, French citizens and politicians found themselves straining to elaborate a "meat laïcite" and refracted their phobias concerning the "Islamization of Europe" onto food production and consumption. In these circles, the word Halal no longer designated an innocent moniker for religiously slaughtered meat, but a symbol of the assault on "traditional" French moral and cultural values, which have historically been articulated, not simply in the matrix of rights, liberty, and republicanism, but in their presence in food itself.

In the midst of the 2012 French presidential campaigns, National Front candidate Marine Le Pen, in her virulent struggle against Islamic communtarianism issued a call to arms against the Halal invasion. In the centrist-Republican magazine Marianne, she was cited as claiming that "In the Ile-de-France, there is no longer one slaughterhouse that isn't Halal. All of the meat consumed in the Ile-de-France is 
exclusively Halal and consumers are not even aware of this" and made clear her desire to take legal action "for trickery". When asked how she knew, she simple responded "I have all the proof needed" [91]. Marianne journalist Jean-Claude Jaillette decided to get a second opinion and consulted Professor Gilbert Mouthon of the Veterninary School of Maison Alfort. Mouthon confirmed the covert Halalization of France's Haram population and observed that "all the slaughtered animals in Ile-de-France are slaughtered according to Halal techniques, for economic reasons. And the phenomenon is spreading in France, where we can estimate that $80 \%$ of sheep are slaughtered according to Halal methods" [91]. According to Jaillette, the reasons for this have little to do with "Islamization", but rather boil down to a laziness propagated in the name of efficiency. He notes that the majority of slaughterhouses are shared between those with Halal derogations and "traditional French" slaughterers and the border between them and their shifts is becoming progressively blurred: When the reserved Halal time is up, secular slaughterers are obliged to "stop the slaughter chains to clean and disinfect them, something that less and less professionals choose to do, preferring to generalize ritual practices and increase their profits" [91]. Such practices have provided Marine Le Pen with a new horizon for the National Front's politics of the "le patrie en danger". They further shocked French food sanitation authorities who remain alarmed at the laxity of slaughterhouse protocol and the possible diffusion of Escherchia coli bacteria.

Moral Panic was the desired result of Le Pen's polemics, a panic which sought to invert Halal's logic of purity in claiming that it was indeed the French who were being poisoned by "strange meat", a panic concerning France's submission to the protocol and norms of others. Preying on populist nationalist passions and flanked by Brigitte Bardot, Le Pen also rhetorically drew parallels between barbarian and anti-human slaughtering practices and anti-humanist barbarians engaged in colonization by meat. In L'est-éclair, UMP deputy, Nicholas Dhuiq, would confirm that Le Pen's observations were "close to reality" and that "she should be applauded for responding to the principle of laïcité...all the way to the plate" [92]. Lambasting Le Pen for cheap politics and conspiracy theories, the French Ministries and government simultaneously rushed to downplay the situation and assure the "French" that their meat was non-Halal and that consumers still had the right to choose what they ate. In $L e$ Figaro, Dhuiq's fellow party member and Sarkozy's Minister of the Interior, Claude Guéant rejected Le Pen's claims as "absolutely false" noting that she was often prone to falsehood [93]. Guéant's defense would be echoed by Dominique Langlois, President of the International Inter-Professional Association of Cattle and Meat, and Jean-Baptiste Galloo, vice-president of the Maison de l'élevage d'Ile-de-France, who would further accuse Le Pen of a gross generalization. Le Pen's polemics did indeed generalize insofar as they elaborately brought into coherence the disparate regimes of animal rights, sanitation and bacteria, and national identity. To the Muslim's concern that his Halal was really Halal, they created a counter-paranoia on the part of the laïque who began to ask if his Haram was really Haram. They further served to reignite longstanding suspicions of the French government's all too warm embrace of Islam, the limits of its various real and symbolic derogations, and the impasses of a post-colonial moment which history may have actually surpassed. Moreover, as in the burqua affair, Le Pen succeeded in galvanizing nationalist anxieties and phobias on the level of the quotidian through a rhetoric of conspiracy: beyond simply drawing attention to the practices and economic interests of Halal and non-Halal slaughtermen, at the core of her narrative, was the assumption that French national identity (which, for her, cannot be rewritten or reconfigured) could be corrupted by 
eating the wrong kind of meat. Just as the believer assumes an ontological identification between his soul and Halal, in Le Pen's civil religion, the same rapport is erected between the sausage of Lyon or Toulouse and the national soul. Some Frenchmen maintain that, in a world of encroaching Halal, eating a sausage will be transformed into an act of resistance.

Le Pen's interest Halal dates back to 2010. It was then that the French Fast Food Chain Quick officially "went Halal" bringing Muslims fond of fast food into a series of tensions with both French national identity and orthodox Islam. While the French were bewildered by their beloved Quick's decision to pander to demographic interests, conservative Imam's were also persuaded that burgers and fries could never be Halal, regardless of how the cattle was slaughtered. Exacerbating the "neither French, neither Algerian" logic that typifies the identities of many second generation Muslims in the banlieue (where no dash can be found to naturalize the term Franco-Algerian), the banlieusard may find himself eating at a Halal Quick that the French renounce along with the imams. For non-Muslim, or non-Halal Frenchmen, Quick's decision to go Halal resonated with nothing short of treason. Although originally Belgian, Quick was absorbed by the French and symbolically emerged as the hexagon's alternative to McDonalds and the nefarious forces of Americanization. At Quick one ate French cheeseburgers. The fast food chain's decision to fully integrate Halal meat in its menus reeked of France giving in to the "other Empire". Begun as a test in early 2010 with Halal menus in eight restaurants, by mid-2012, Quick had 23, 100\% Halal franchises in France with the total number anticipated to grow.

In Libération (February 15th, 2010), infuriated by the presence of turkey bacon in the classic Quick "Strong Bacon Burger," Le Pen rallied against Halal Quick under the banner of freedom of choice and in the name of a refusal to fill the coffers of Halal certification agencies: "Is it normal that everyone who goes to Quick are obliged, through the intermediary of Halal meat, to pay a tax that goes to Islamic Certification organizations" [94]? Obligatory Halal was code for the destruction of French liberty and republican autonomy and also cast as a mechanism which duped the French consumer into financing Islam and Islamic enterprises. Le Pen's pronouncements demanded that secularism thus be extended to not only the division between church and state, but to the division between mosque and fast-food restaurant. Communataranism seemingly appeared to be bolstered by French fast-food establishments whose decision to not offer both Halal and non-Halal burgers, a choice informed by purely economic interests, was seen as pandering, accommodating, and selling out. The problem, of course, was not the existence of all Halal restaurants in France; Le Pen and co. have yet to ask kabob shops in the banlieue and other "Halal zones" to serve both Halal and non-Halal meals. The problem, rather, was that it was Quick, a French multi-national whic was apparently "co-opted" by Muslim buying power. Anti-Halal, Anti-Islamist, hardline secularist faction Résistance Républicaine [95], one of the many groups who advocated a total boycott of Quick, went so far as to speak of "Halal Apartheid”. In FrancaisdeFrance, Christine Tasin, Résistance Républicaine's president, lamented that "what we are constructing in France of 2011, is a world that resembles more and more South Africa in the 1980s, with the deliberate organization of two types of populations" [96]. Republican secularism, like animal rights, can also be appropriated by the center and right as a tendentious discourse through which to articulate anxieties about Islam in Europe. Tasin, indeed, considers Halal to be a geopolitical strategy, a kind of conquering by meat: “The next steps. They're clear: make disappear, little by little, non-Halal commerce in Islamisized zones, adapt the French to eating Halal to the detriment of other 
food in their neighborhoods, and little by little, generalize Halal everywhere" [96]. Yet, if Halal represents a subterranean mode of conquest, its primary arms and modes of implementation are not cultural, or religious, but economic. Piety is melded into liberal market logics, which are, by nature, "neutral" and born of long historical processes where religious freedom (not secularism) and economic self-determinism came to be simultaneously incarnated in the spirit of free enterprise. The real issue, it seems, with the Halal revolution, is whether and how the religious can potentially come to eclipse such neutrality and render the spirit of free enterprise, less free (with financial, spiritual, and moral "prices" to pay, etc.).

Quick, an apparently "neutral" burger purveyor, found itself selling "religious meat". Reticent to enter into the political fray or take sides, Quick contended that its new menu was an experiment destined to "gauge the interest and technical feasibility of this commercial offer...we simply want to see how our clientele responds" [97]. In launching such an experiment, Quick aspired to enter a market estimated to, according to SOLIS, have a net worth of more than 5.5 million Euros. Its decision to respond to the changing demographics of its clientele and their tastes was one that was made by a private corporation, which, although a simple of national fast food, was in no way affiliated with the state. Following from this, private corporations are not required to act as political actors and their choices need not reflect the ethos or spirit of any set of ideologies or values (particularly when it comes to burgers). They may then engage in commerce that is deemed "communitarian", "local", or "demand sensitive". But Quick was derided for cashing in on the Halal market and thus ostensibly supporting Islamic communatarianism. Of course, no clear ethical criteria exist to aid us in identifying the line between "profiting from them" and "supporting the world view"; laisser-faire capitalism obviously teaches that the contract established between the seller and the consumer strictly concerns the integrity of the object being bought and the cash paid for it and not the ideological bond shared by the two parties. Yet, does the same logic apply to the exchange of religious goods? And, as laïcité does not apply to food and free enterprise, the state cannot technically ask Quick to "diversify" its menu to meet the needs of non-Halal clientele. Indeed the terms "diversity", "discrimination", and "nation" were displaced from their traditional discourses in the case of Quick. Complex signifiers, these terms were readily circulated to both apologize for Quick's experiment and against it as well.

The socialist mayor of Roubaix, René Vandierendonck, for instance, accused Quick of "discrimination", which was all the more reproachable in light of the fact that Quick was a "national brand" as it was "the property of la caisse des depots, the financial arm of the State" [98]. Following from this, Quick's affiliation with la caisse des depots was interpreted as having altered its structure from a private franchise to a "public good" and de facto implicated the Republic as subtly approving pro-Halal policy. However, it is again not clear whether a private corporation's usage of a public bank and credit institution transforms it into state restaurant serving state burgers. Fadela Amera, at the time Sarkozy's Secretary of State in Charge of Urban Politics, was among those who sought to depoliticize the issue and jettison it from on-going debates on national identity and Islamic communtarianism. For Amera, "in this fast-food affair we confuse communitarianism with diversity...communitarianism is something else. The full veil (voile intégral), now that's a scandal" (cited in [98]). Two points merit being made in response to Amera's comments. Firstly, one needs to interrogate the lines of demarcation between the phenomena of communitarianism and diversity. In contrasting diversity to communitarianism, Amera affirms that the toleration that typifies diversity policy should not be 
extended to those who seek comfort and security in the folds of clan, kin, and collective ritual. In doing so, the communtarian is an "other" who refuses the interpellation of the state and indeed may oppose it in the name of his own world, cultural mores, and laws. Is Halal Quick communitarian? The answer would appear to be yes insofar as only one type of cuisine designated for one type of consumer is served at these restaurants producing a strange breed of capitalist communtarianism within the confines of the "national" Quick. In other words, one voice and one taste prevails at the Halal Quick and to the detriment of others. Of course, Quick, like any community in France, is not a microcosm and certainly does not explicitly advocate an ethos or politics, which calls into question the Republic. One must also ask what the long-term repercussions of Halal Quick proliferation will be on a nation whose very social and moral structure is reflected in the notions of "vivre ensemble" and "solidarity". Is Halal Quick a sign of France's embrace of multiculturalism or an index of the limits of Republican compromise, which can only finish in social fragmentation. Secondly, apropos diversity, in the context of Amera's comments, it would seem to be understood as the tolerance of a religiously based menu in a restaurant whose historic clientele and spirit have been resolutely neutral and "open". It would also entail that diversity be understood as the inclusion of the other, of that which is non-white, non-French, and non-Haram. Diversity is not an autonomous construct, but rather a conditional category (diverse in relation to what), which depends on the state's acknowledgement of and will to tolerate and embolden the other. In a more literal sense, cultural diversity would refer to the co-existence of religious and identitarian singularities. Is Halal Quick a harbinger of diversity? The response here is equally complex as it depends on what level or dimension of governmentality, the "diverse" is being constituted. On the level of the nation and the geography of France, the existence of Halal Quicks and Halal restaurants in general would superficially point to a diversity of cuisine in the hexagon. What, however, becomes problematic in such an assessment is the measurement of the co-existence and the cultural exchange that takes place between the Halal and the non-Halal which fosters real diversity (a good idea in principle) instead of calling diverse those communtarianisms which happen to exist side by side. Amera's argument would also lead one to believe that the banlieus in which the majority of Halal Quicks are located, banlieues that are notoriously coded as symbolic and geographic peripheries for various "ethno-religious classes" (and now cuisine) function as testaments to French diversity. On the level of the Halal Quick experience itself, the absence of non-Halal choices on the menu, while "recognizing" a "diversity of tastes" in the nation, symbolically forecloses the possibility of pluralist multiplicity. The invocation of "diversity" in such a loose manner demands that we ask what and who is being included, by whom, where, and how. Pursuing such a line of questioning may reveal inclusion to be a tenuous notion at best. These are important elements of a political conversation that is perpetually deferred. Instead, these questions are subtextually posed, perverted, and coded in polemics about hamburgers.

Amera's distinction between the veil and Halal also has a series of theoretical repercussions. If we move beyond the ranting, xenophobic polemics, and chauvinism of debate, the "scandal" of the veil is a response to its status as an emblem of submission which thus runs against the grain of Republican ideals of autonomy, free thought, and secular reason whose primary of bastion of dissemination is, of course, l'école républicaine. In a more concrete sense, as Cécile Laborde has argued, the "official republican" contestation of the veil emerges from anxieties concerning among other things: the introduction of signs of private difference and religious difference in the public sphere; the primacy of 
the believer over the citizen; the infringement on equality amongst pupils in schools; the undermining of the civic ethos of those schools; and the assault on the general French scheme of religious freedom ([99], pp. 53-54). These criteria do not lend themselves to being transposed onto Halal in any tidy manner, but does open a series of avenues for important political theoretical reflection. Should a Halal butcher or a Halal burger be taken as a "sign" of private or religious difference and if so, how should such signs be governed and/or managed in the public sphere? Is the choice to eat a Halal an expression of submission and domination or an articulation of autonomy as non-domination from the forces of Europe and Globalization (complicated ever more by a Quick Halal burger)? Does the disproportion of Halal restaurants to non-Halal restaurants in many sections of the French banlieue constitute an affront to or a rereading of normative paradigms of French citizenship vis à vis food? Is such a question, in some way impertinent, insofar as dining and food consumption should be treated as "private matters"? Where does the expression of religious freedom mutate into the much-maligned category of the communitarian? Should such considerations be equally extended to other religious foods and where does an "ethnic food" begin to incarnate religious properties, etc.? Unfortunately, the possibility of posing such critical questions in the public sphere is thwarted by the political polarization of Islam in France, which traverses from La Pen's histrionic conspiracy theories to, for instance, the pronouncements of Cécile Duflot, national secretary of the Green party, who deems any anti-Halal sentiment among the French to be symptoms of "Islamophobia" [95]. The foreclosure of such a debate, which is really about Islam, ostensibly points to the growing sclerosis of the Republic. Any serious and respectful "republican": treatment of the Halal question and the beliefs of those who consume it would avoid this sclerosis and the three typical responses which characterize it, responses which range from the odious to the condescending: (1) the extreme-right's thesis of "France under attack", and its concurrent desire to either halt all immigration or ship all foreigners back home, (2) the more centrist liberal reading which claims that if we were to just get to know them, we would see that they were just like us (with Islamic studies as the primary site for such rapprochement, and (3) the gauchiste tendency to claim that either there is no problem with Islam in France (although, we seemingly cannot stop talking about it) or disable all critical discourse concerning Islam as non-politically correct Islamophobia.

Sentiments among the Halal community concerning the Quick affair further reflected ambivalences, which offered a measure of various sentiments on the burger restaurant's apparent role in "social inclusion". For Al-Kanz.org, a web portal devoted to Muslim and Halal consumption, the Quick scandal indeed functioned as a polemic about Muslims in France and not food:

Would we have all this filth in the media if Quick had chosen another position, another niche, perhaps like organic foods? What about a Mexican or Chinese themed Quick, would that have the same resonance in the media, no, of course not...the frustration of those who can no longer eat bacon at Quick is real and legitimate. However, the same does not go for the demagogic, political, and often stupid responses to Quick. And if it is really the communatarianism that poses the problem, why do we tolerate in midst of Paris, at 240 boulevard Voltaire in the 11th arrondissement, a totally Kosher Franprix? [100].

Such a line of questioning is cogent and reasonable and takes the Republic to task in drawing attention to its own "bad faith". The question of the wearing of crucifixes, religious lockets, Hindu ceremonial bracelets, and other symbols of religious submission was only mildly evoked during the 
polemics surrounding the veiled only to be brushed aside as distracting. Respectively, in the Halal affair, the rigor of France's food lä̈cité has yet to be applied to other "ethno-religious" fare. Such laxity only serves to confirm Alain Badiou's observation that diversity politics ultimately obfuscate any politico-philosophical will to truth insofar as the "self-declared apostles of ethics and of the 'right to difference' are clearly horrified by any v igorously sustained difference...this celebrated 'other' is acceptable only he is a good other-which is to say what, exactly, if not the same as us. Respect for differences, of course! But on condition that the different be parliamentary-democratic, pro free-market economics, in favor of freedom of opinion, feminism, the environment..." ([101], p. 24). Islam appears to only fulfill some of these requirements.

Many hard-line Catholics contend that the future of Catholicism depend on the rediscovery of the density of belief; a good Catholic will believe in the real existence of the Devil, fire and brimstone, Jesus walking on water etc. While we should certainly refrain from advocating the existence of the super-natural, such redensification may be equally necessary for Republicanism, if it is to continue to understand itself (and it may not choose to) as the civil religion that it was founded as. Yet, redensification need not devolve into the totalitarian tendency and must be supplemented with a respective process of recalibration. In other words, Republican secularism must engage with all food cultures in a total and across-the-board manner, but in the process reflect on the limits and possibilities of its assumptions in the context of the transnational marketplace. This need not take the form of any Republican compromise. Rather, it may also result in new modes of tracking the common good, the common interest, and the collective will to non-domination.

In addition, for many Muslims the pollution of Halal by Quick's rabid capitalism was a point of deep consternation as it implicitly blurred ever more the already nebulous lines between Halal and Haram. Clichois Nasser, in an interview with Gilles Kepel, objected to Quick's politics, noting that "we can live quite well without Quick Halal, and their strategy is purely mercantile. I'd prefer that they though of me firstly as a Muslim and respected my practices as opposed to thinking of me as a potential client" (cited in [5], p. 69). Quick's pandering to the religious is thus treated as an offense to the sanctity of the religious, a sanctity, which is corrupted by Quick's relatively "non-Halal" relation to profit. Nasser's anger is also the consequence of his discomfort in being reified as a religious consumer, a religious client, in the capitalist market. Here his faith is reduced to demographic statistic and stripped of all passional resonance. Halal, for those such as Nasser, will not be recuperated. Eating at the Quick also reshapes what constitutes Islamic practice in relation to a largely consumerist context. In other words, while KFC and Quick may serve Halal food, does their implication in the hyper-modern capitalist market place and their concurrent catering to non-Halal render null and void any claims to Halal that they might have, regardless of the nature of their meat. Hence, as Kepel also reports, many believers, already hostile to the sub-culture of many second-generations Muslims in the banlieue, railed against Quick's entrance into it: "for you Islam is eating at Quick-I'm sure you go to Friday prayers, you circle with your car, you don't find a parking spot, you leave...but then you have all of these who have waited in line for an hour at Quick to eat a 'Giant'...the Halal market exasperate sme, to see all these people go Halal to make money that doesn't serve the community..." (cited in [5], p. 70). In this reading Quick Halal is not only representative of a "sub-Islam" born of half-measures and a taste for ketchup, but also potentially dangerous for the umma as the profits from Quick Halal go to Haram CEOs and ultimately fund the illicit lifestyles of wealthy non-Muslims and not the building of 
the local mosque. Not only does Quick signify the degradation of purer forms of Islam, but it also hijacks local commerce. And, of course, in principle local commerce is good for the neighborhood. But here one wonders whether it does not engender divisive forms of economic-religious "communtarianism" and the construction of urban "Halal communes".

According to Olivier Roy, the persistence of these debates serves to, in fact, mask the power of Halal, which resides in its infinite malleability to global flows. However, these polemics also prove, as he further notes, that many believers, particularly of the neo-fundamentalist persuasion, lack taste and culinary refinement:

Food versus culture is a good example between code and culture. Neofundamentalists care nothing for cuisine. Anything Halal is good, whatever the basic ingredients and the recipe. When they open a restaurant it never promotes Ottoman or Moroccan cuisine, but halal food, and more often than not will simply offer the usual Western fast food products. Similarly, halal dress can be based on Western raincoats, gloves, fashionable scarves (cha-Dior as the Iranians joke), and so on. Halal is thus a code that is adaptable to any culture. Objects cease to have history and to be culturally meaningful; once chosen they meet a normative requirement and do not refer to any specific culture...for the neofundamentalist the hamburger is culturally neutral as long as it if made along the lines of a religious norm (halal). ([102], p. 271).

Halal has no territory or nation. Rather, it is a centerless and roving quality to be consumed anywhere in the global desert. However, its de-connecting from local, historical, and rooted forms of food tradition, not only give it a vaporous and empty quality, but also detach it from histories of recipes, of modes of cooking, of cultivations of national taste and cuisine. Its adaptability is therefore one of a loss and a gain; the loss of culturally rooted food traditions and dining rituals and the gain of a global network of hamburgers and fashionable scarves which allow the believer to be a believer wherever he wants.

In the winter of 2010, just as the Quick was beginning its "experiment", the French scored a decisive victory and "saved" French cuisine from its inundation by an assortment of roving global codes and fusions; The United Nationes Educational, Scientific, and Cultural Organisation (UNESCO) officially recognized French gastronomy as constituting the Intangible Cultural Heritage of Humanity. Added to UNESCO's celebrated intangible heritage list by the Intergovernmental Committee for the Safeguarding of the Intangible Cultural Heritage, was "French food", along with Chinese Acupuncture, Spanish Flamenco Dance and the traditional Peking Opera. For the intergovernmental committee, French Gastronomy satisfied the requirements of the cultural heritage convention insofar as it "plays an active social role within its community and is transmitted from generation to generation as part of its identity" and could "function as a catalyst for mutual respect and intercultural dialogue"; it was further demanded that "Individuals called gastronomes, who possess deep knowledge of the tradition and preserve its memory, watch over the living practice of the rites, thus contributing to their oral and/or written transmission, in particular to younger generations." ([103], my emphasis). The heritage proposal focused on the French gastronomic meal (the Sunday meal, feasts, weddings, banquets, etc.) and not the jambon-beurre sandwich scarfed down on the metro. It was also a rejection of "fast" food and a hommage to the long (often interminably) French lunch, an aesthetics of slowness and savoring, fine tablecloth, and family. While, of course, no mention of Halal and its nefarious implications for French food was mentioned in the dossier for candidacy, against the backdrop of 
Sarkozy's France and the growing scandalization for Halal, French gastronomy's inscription as intangible world heritage represented, for many, a triumph over France's potential Halalization. Furthermore, one could not elide the religious resonances that loomed in the discourse of the French: French gastronomy was ritual, morality, collective memory, and the key to social cohesion. And here, choosing the right wine for the right meat was akin to praying, meditation, making sacred, or any religious technology, yet it was a technology for and about the French bourgeois. Above all, what the convention confirmed was that French food had to be saved, preserved, and transmitted to future generations-but what did it need to be saved from? Globalization, Americanization, Halal, or the perfect "fusion" of the three, the Halal burgers and KFC? French food was presented as under threat, on the verge of extinction, and endangered. And if it needed to be saved in order to function as a conduit towards greater intercultural dialogue, one also had to reflect on who was to be invited to the dinner table or apéro, which like the public sphere, are defined by certain shared cultural mores, paradigms of secular communicative reason, and etiquette.

I had the occasion to gauge the responses of UNESCO's international personnel to the induction of French cuisine to what, in the world of UNESCO, people simply "the list". One Tunisian colleague insisted on the deep politicization of the decision and its relation to a particular historic moment in France's on-going struggle with the fluxes of globalization: "We should remember that when they say French gastronomy, they're saying France. You can't separate the two. And the decision to put French food on the heritage list obviously reflects French anxieties about the loss of its nation or 'fortress France' to its immigrant populations." One Malian member of the secretariat added "it is not clear to me what French food is anymore. I mean if you have a baguette, some red wine, and steak, are you eating French food? Is it about preparation? What if a cook threw a little curry or tumeric into the soup...would it stop being French gastronomy or is that Ok, because it's a famous French chef?" The responses amongst French varied. Some echoed Sarkozy's appeals to French culinary pride and affirmed that "French food is the best in the world and deserves to be treated as heritage. Our history is also bound in the meal-it's a deep cultural thing." One other Frenchmen rejected such rhetoric as implicitly "nationalist" and further lamented, "French food, well that's all we really have left, isn't it?" Yet another French fonctionnaire opined "this is ridiculous, food, although intangible, should certainly not be hailed as 'heritage'.... are you telling me that crème fraiche is on the same level as Buddhist chanting in Ladakh or Rajasthani folk songs." In strange antagonism with Amera's arguments about Quick Halal's facilitation of diversity, French ambassador to UNESCO Catherine Colonna remarked that French gastronomy "makes a contribution to cultural diversity... The French love getting together to eat and drink well and enjoy good times in such a manner. It is part of our tradition - a quite active tradition" [104]. No one asked that Colonna clarify who "the French" were and whether those French-born Muslims at the Halal Quick at La Courneuve on Sundays were enjoying the good times she spoke of. In Halal Quick and French gastronomy, one glimpses two invocations of food diversity, which, suffice it to say, collide with one another in terms of class, race, and "culture".

One can only wonder if Roland Barthes would cringe or rejoice at UNESCO's decision, whether he would lament its decision as yet another symbolic victory for the French bourgeois or succumb to his own love of patrie and celebrate with a meal. Barthes' celebrated ode to steak-frites still reads as a manifesto for food and the French Nation one where the blood of the biftek is the blood that flows through France. As he observes, 
Flood bloodedness is the raison d'etre of steak...to eat steak rare therefore represents both a nature and a morality...Like wine, steak is in France a basic element, nationalized even more than socialized. It figures in all the surroundings of alimentary life...moreover it is a French possession...steak is adored here with a supplementary virtue of elegance, for amongst the apparent complexity of exotic cooking, it is food which unites, one feels succulence and simplicity. Being part of the nation, it follows the index of patriotic values...Commonly associated with chips, steak communicates national glamour to them: chips are nostalgic and patriotic like steak...the alimentary sign of Frenchness. ([105], pp. 62-64).

The UNESCO decision will serve to "protect" steak-frites and with it, the moral and nationalist mythos it embodies, its virtues, and glamour. Protecting steak-frites means also being on guard against its lowly competitor, a usurper of the grand tradition of meat and potatoes, one with decidedly different moral valences and national identities, one that is also far less glamorous: the grec-frites.

A remote cousin of the Greek gyros, the grec-frites or Döner Kabob is actually Turkish in origin. It is a $100 \%$ Halal sandwich composed of processed and reheated lamb meat which is "shaven" off a revolving lamb tower or vertical spit. The pieces of shaved meat are then placed in a pita with onions and lettuce and a choice of sauces (ketchup, mayonnaise, harissa, "white sauce", barbeque). The sandwich is then placed on a pile of usually underdone french-fries. For those who choose to get their "grec" to go, a standard yellow styrofoam container is provided. For those who, on the contrary, prefer to "dine" their grec-frites can be upgraded to an "assiette grec" which adds spicy grains to the dish. A staple of Halal fast food, the grec is usually not consumed with wine, but rather with a Fanta. According to Kebab-frites.com, the average grec contains anywhere from 800-900 calories, with the fries adding 400 calories, and the Fanta an additional 110, for a total of approximately 1350 calories [106]. The average price of a grec-frites is 5 euros.

Although Halal, the grec-frites is not coded in any strict religious manner. It is the dish of choice for students and young people for the end of a long night of drinking. Cheaper than Mcdonalds and Quick and, from a caloric perspective, infinitely more fulfilling, it is a rapid and efficient way to ward off hunger and maintain a full stomach for hours. Deemed by many food snobs and gastronomes as the epitomy of abjection, the grec-frites is the food of choice for those on a budget. Yet, there do indeed exist grec-frites connaisseurs who insist that the sandwiches served at one restaurant are better than those served at others. It is not easily digested and leaves a strong spicy sodium-laced aftertaste in the mouth and body. It is a cuisine designed for mobility. All of its contents are placed in the one small yellow styrofoam container which can be easily placed one one's lap or held in one hand. The grec-frites is often eaten on the metro or the public bus, its pungent odors (salt, ketchup, mayonnaise, grease) do not titillate. Rather, they invade. The grec-frites is often sold at restaurants called Medina, Tunisian Pearl, or the Casbah. Yet, it is a fully deterritorialized cuisine, bearing little connection to its Turkish origins, let alone the Maghreb, and promotes no set of national values, moral codes, or traditions. One does not participate in roots or activates waves of collective memory when eating a Kebab. It goes where Arab and North African immigrant entrepreneurs go. Its Halalness also appears to be of little importance to most who consume it who are both Muslim and non-Muslim. Nonetheless, one could not claim that the grec-frites promotes cultural diversity or engenders inter-cultural dialogue.

While not the object of scandal in the same manner as Halal Quick, the rapid proliferation of kebab restaurants, particularly in the French banlieue (where one can speak of both Halal Zones and grec-frites zones), has raised concerns about the changing face of French commerce. In downtown 
Aubervilliers, for instance, within a one-kilometer radius of the Town Hall, one finds 20 Kebab shops (in comparison to seven full fledged "French" bistros or brasseries, many of whom serve the obligatory Friday couscous). The municipality has unsuccessfully launched an official "Food and Commerce Diversification" campaign, a necessary step in its dream of eventual Boboisation. But the Bobos have yet to arrive en masse and the relative success of grec-frites in Aubervilliers is due, in part, to the tastes and incomes of those who inhabit the banlieue, but also to the ease with which a kebab shop can be opened and run. One need only rent a locale, purchase a deep fryer and Kebab spit, a small fridge for sodas, tables, chairs, and plates and utensils etc. No experienced cooks or chefs are needed as shaving meat is a relatively rudimentary task. The majority of Kebab shops do not accept credit cards and deal strictly in cash, so as to avoid various fees and often evade taxes. As most of the grec-frites sold are taken to go, interior décor is usually sparse with some restaurants appearing as yellow rooms with plastic tables and chairs. And of course, unlike Quick, these shops all have the word Halal emblazoned on their windows.

The municipality of Aubervilliers, of course, has no jurisdiction over the explosion of these free enterprises in its community. The most it can do is offer subventions to the local Nicolas (a well-known French wine shop) and a newly opened Italian food store where one can pay upwards of 10 euros for a kilogram of sausage. However, the introduction of these non-Halal elements into a largely Halal commerce zone has done little to convince Albertivillians of the rich food diversity found in their neighborhood. With little exception, Aubervilliers' pizzerias and Chinese restaurants are also Halal. The last non-Halal butcher in downtown Aubervilliers closed in the summer of 2010 to be replaced by an AVS affiliated team (with the implication that on Sundays, non-Halal meat can only be purchased at the local supermarkets which close at 1:00 p.m.). A sushi restaurant lasted less than a year, even after adding a Halal sticker to its window during its final days of operation. Halal meals have also been introduced in public school class trips to the chagrin of many parents, thus also raising the question, like the veil, of the introduction of religious symbols in l'école républicain. The various markets of Aubervillier and corner stores rarely carry bacon or sausage. However, they do sell beer (some only before 8:00 p.m.). When I asked one Islamic market owner how she reconciled her faith with the selling of Haram, she noted that she made a yearly pilgrimage to Mecca to purify her soul, business, and money. Hence, in Aubervilliers code does appear to eclipse cuisine and culture, but "code" is also imbricated, not only in taste and belief, but in class and buying power (or the lack thereof) and a decidedly and often deliberately non-bourgeois understanding of cultural capital.

\section{Conclusion: Borders and Purity}

Halal is a mobile and mutating political, social, and corporal border. As such it must be apprehended in terms of larger will to distinction that has typified the history of Islam and its always-already global umma. Unverifiable and subject to a multiplicity of variations and, the border fluctuates and is ridden by weak spots, points of degradation, and broken foundations. Islam has no site of central command, no pope, and no set of firm laws that specify what should constitute the Halal border whose integrity is subject to the interpretation of imams, certification agencies, and believers themselves. Yet, the integrity of the border may be less important than its symbolic invocation or status as a simulacrum of imagined purity and magical spiritual properties. The construction and deconstruction of the border can be violent, alienating, and potentially stigmatizing. Fatema Mernissi 
argues that the core of Islam is found in its obsession with borders, walls, and boundaries. But, for Mernissi, the key question is not how these borders are built, razed, and rebuilt, but rather what they really protect the umma from, what they keep out: “...I instinctually understood very young that behind every boundary something terrifying is hiding. It is fear, or rather fears..." ([107], p. 8). What is Halal scared of? Halal is scared of mixity, non-differentiation, liquid life, anomie, and unbridled flows-precisely what characterizes global and transnational processes. What then does Halal want? It wants a transportable border that can ward off the fieriness of such flows at the micro-level of meat. It desires a moveable foundation in an age typified by giddy nihilism, an age where hedonism is an imperative.

Halal anchors the nomadic believer and offers a modicum of psychic and spiritual security. And in principle, there is certainly nothing implicitly wrong with the desire for security. Yet, as Terry Eagleton reminds us that there is a vast gulf between the need for a semblance of security and foundations and their rabid over-determination:

Most people expect a spot of security in their personal lives, so why shouldn't they demand it in social life as well? They are not necessarily fundamentalists for doing so. Fundamentalism is just a diseased version of this desire. It is a neurotic hunt for solid foundations to our existence, an inability that human life is a matter not of treading on thin air, but of roughness. Roughness from a fundamentalist viewpoint can only look like an a disastrous lack of clarity and exactitude...it is not surprising that fundamentalism can see nothing in the body and sexuality except the perils to be suppressed since in one sense all flesh is rough...The fundamentalist is adrift on the rough ground of social life, nostalgic for the pure ice of absolute certainty where you can think but not walk. He is really a more pathological version of the conservative-for the conservative, too, suspects that if there are not watertight rules and exact limits then there can only be chaos ([108], pp. 204-05).

The ground of social life grows ever rougher with the advent of globalization and needs even firmer organizing principles and mechanisms of striation. Halal may function as one such principle and span the gamut from the reasonable desire for security to an overwrought fundamentalism, which betrays a deep seated discomfort with the body, a body which needs to be continually purged and made sacred. Yet, as a mobile foundation, Halal offers no real certainty. It too is rough and besieged by its own lack of clarity. Hence the call for greater standards, greater security, and greater purity.

Purity, particularly when mixed with moral self-righteousness, can become a dangerous game, which not only places the believer in an impossible situation, but obliges him to erect his persona against roughness and the impure. Purity can lead to hatred of the impure. Purity can become severe, paranoiac and obsessive. And Purity never admits that in the end, there is no such thing-that all there is roughness and rules that forever bend. But purity, certainly in the case of Halal, can also spawn a multi-million dollar global industry. As long as roughness is disavowed, as long as the certainty of the rule is fetishized as the only means of making sense of experience, this business will continue to thrive. One can only wonder what the ritually slaughtered animal would make of all this.

\section{Conflicts of Interest}

The author declares no conflict of interest. 


\section{References and Notes}

1. Zizek, Slavoj. Defense of Lost Causes. London/New York: Verso, 2008.

2. Riaz, Mian N., and Muhammed M. Chaudry. Halal Food Production. Boca Raton: CRC Press, 2004.

3. Hanzaee, Kambiz Heidarzadeh, and Mohammad Reza Ramezani. "Intention to halal products in world markets." Interdisciplinary Journal of Research in Business 1 (2011): 1-7.

4. Bourdieu, Pierre. "Genesis and structure of the religious field." Comparative Social Research 13 (1991): 1-44.

5. Kepel, Gilles. Quatre-Vingt Treize. Paris: Gallimard, 2012.

6. Simoons, Frederic J. Eat Not This Flesh: Food Avoidances from Prehistory to the Present . Madison: University of Wisconsin Press, 1994.

7. Diener, Paul, and Eugene E. Robkin. "Ecology, evolution, and the search for cultural origins: The question of islamic pig prohibition." Current Anthropology 19 (1978): 493-540.

8. Harris, Marvin. The Sacred Cow and the Abominable Pig. New York: Simon \& Schuster Press, 1985.

9. Lobban, Richard A. "Pigs and their prohibition." International Journal of Middle East Studies 26 (1994): 57-75.

10. Durkheim, Emile, and Marcel Mauss. Primitive Classification. Translated by Rodney Needham. Chicago: University of Chicago Press, 1993.

11. Abdel-Haleem, Muhammad A.S., trans. The Qu'ran. Oxford: Oxford University Press, 2004.

12. Douglas, Mary. Purity and Danger: An Analysis of the Concepts of Pollution and Taboo London: Ark Paperbacks, 1988.

13. Mukherjee, S. Romi. "After ontology, after essence: Recasting the 'Human' from within the socio-techno-interface." Caliban 13 (2013): 197-218.

14. Douglas, Mary. "Deciphering a meal.” Daedalus 101 (1972): 61-81.

15. Singer, Emily. "Pig to Human Transplants on the Horizon." MIT Technology Review, 6 October 2006. http://www.technologyreview.com/news/406651/pig-to-human-transplants-on-the-horizon/.

16. Prather, Randall S., Shen, Miaoda, and Dai, Yifan. "Genetically modified pigs for medicine and agriculture.” Biotechnology and Genetic Engineering Reviews 25 (2008): 245-66.

17. Bonne, Karijn, and Wim Verbeke. "Religious values informing halal meat production and the control and delivery of halal credence quality." Agriculture and Human Values 25 (2008): 35-47.

18. Baudrillard, Jean. Simulacra and Simulation. Translated by Sheila Faria Glaser. Ann Arbor: University of Michigan Press, 1994.

19. Cornerstone Farm Ventures. Available online: http://www.cornerstone-farm.com/equipment/ humane-halal-slaughter-knife (accessed on 6 December 2012).

20. Bleher, Sahib Mustaqim. "The halal slaughter controvesy: Do animal rights activists protect the sheep or the butcher?" Available online: http://www.mustaqim.co.uk/printhalal.htm (accessed on 6 December 2012).

21. Leduff, Charles. “At a Slaughterhouse, Some Things Never Die.” In Zoontologies: The Question of the Animal. Edited by Cary Wolfe. Minneapolis: University of Minnesota Press, 2003.

22. Gibson, T.J., C.B. Johnson, J.C. Murrell, C.M. Hulls, S.L. Mitchinson, K.J. Stafford, A.C. Johnstone, and Mellor D.J. "Electrocencephalographic responses of halothane-anaesthetised 
calves to slaughter by ventral-neck incision without prior stunning." New Zealand Veterinary Journal 57 (2009): 77-85.

23. Andy Coghlan. "Animals Feel the Pain of Religious Slaughter.” The New Scientist, 13 October 2009. http://www.newscientist.com/article/dn17972-animals-feel-the-pain-of-religious-slaughter.html.

24. Farm Animal Welfare Council. Report on the Welfare of Farmed Animals at Slaughter or Killing. London: Defra Publicatons, 2003.

25. Scherer, Logan. "The cruelty behind muslim ritual slaughter." People for the Ethical Treatment of Animals (PETA), 8 December 2009. Available online: http://www.peta.org/ b/thepetafiles/archive/2009/12/08/the-cruelty-behind-muslim-ritual-slaughter.aspx (accessed on 6 December 2012).

26. Schulze, W., H. Schultze-Petzold, A.S. Hazem, and R. Gross. "Attempts to objectify pain and consciousness in conventional (captive bolt pistol stunning) and ritual (Islamic method of cutting with knife) methods of slaughtering sheep and calves." Deutsche Tieraerztliche Wochenschrift 85 (1978): 62-66.

27. Majid Katme, A. "Halal Slaughter is Most Humane." Available online: http://www.oocities.org/mutmainaa/food/halal_slaughter.html (accessed on 6 December 2012).

28. Assembly of Muslim Jurists of America. Available online: https://www.amjaonline.org/ journals/imams-conference/9/10.pdf (accessed on 6 December 2012).

29. European Commission Convention for the Protection of Animals for Slaughter. Available online: http://ec.europa.eu/food/animal/welfare/references/slaughter/jour137_en.pdf (accessed on 6 December 2012).

30. On religious rights as "specific rights" and "general rights", see: Laborde, Cécile. "Political liberalism and religion: On separation and establishment." Journal of Political Philosophy 21 (2005): 1-20.

31. New Jersey Bureau of Consumer Affairs. Available online: http://www.njconsumeraffairs.gov/ ocp/halal.htm (accessed on 7 December 2012).

32. Halal Food Council of Europe. Available online: http://www.hfce.eu/quickguide.html (accessed on 7 December 2012).

33. Bergaud-Blacker, Florence. "De la viande halal à l'halal food: Comment le halal s'est développé en France ?" Revue Européene des Migrations Internationales 21 (2005): 125-47.

34. Bergaud-Blacker, Florence. "La viande halal peut-elle financer le culte musulman?" Anthropologie et économie 84 (2001): 145-71.

35. Unstunned Halal. Available online: http://www.unstunnedhalal.com/news/view/?id=46 (accessed on 7 December 2012).

36. Smith, David. "Cruelty of the worst kind: Religious Slaughter, Xenophobia, and the German Greens." Central European History 40 (2007): 89-115.

37. The Conversation. Available online: http://theconversation.edu.au/explainer-the-ethics-of-ritualslaughter-2101 (accessed on 7 December 2012).

38. The Islam Monitor. Available online: http://islammonitor.org/index.php?option= com_content\&task=view\&id=61\&Itemid=64 (accessed on 8 December 2012).

39. Sheikh Shady Al Suleiman. "Halal living." October 2012. Available online: http://www.youtube.com/watch?v=1Bh9FPp9-OQ (accessed on 9 December 2012). 
40. Wood, John. "Halal Chicken Sold at KFC may not be Real Halal." Food Manufacture UK, 19 September 2012, http://www.foodmanufacture.co.uk/Regulation/Halal-chicken-sold-at-KFCmay-not-be-real-halal.

41. Halal Food Authority, Press Release. Available online: http://www.halalfoodauthority.com/ Press-release-ulema.pdf (accessed on 9 December 2012).

42. On Halal Science, see inter alia: Hargin, K.D. "Authenticity issues in meat and meat products." Meat Science 43 (1996): 277-89; Fajardo, Violeta, González, Isabel, Rojas, María, García, Teresa, and Martín, Rosario. "A review of current PCR-based methodologies for the authentication of meats from game animal species." Trends in Food Science \& Technology 21 (2010): 408-21; Ballin, Nicole Z. "Authentication of meat and meat products." Meat Science 86 (2010): 577-87.

43. Agriculture and Horticulture Board. EBLX Report: The Halal Meat Market: Specialist Supply Chain Structures and Consumer Purchas e and Consumption Profiles in England . Kenilworth: EBLX Press, 2010.

44. Bergeaud-Blackler, Florence, and Bruno Bernard. Comprendre le Halal. Liege: Edipro, 2010.

45. Fischer, Johan. "Religion, science, and markets: Modern halal production, trade, and consumption." European Molecular Biology Association 9 (2008): 828-31.

46. Mustapha. Aubervilliers, France. Personal Communication, 26 December 2012.

47. Hakim. Saint Denis, France. Personal Communication, 23 December 2012.

48. Lahouri, Besma, and Boris "L'argent de l'Islam." L'Express, 11 November 2002. Available online: http://www.lexpress.fr/actualite/societe/religion/l-argent-de-1-islam_497530.html (accessed on 28 December 2012).

49. Halal Media. “'Halal Pork' Scandal Enrages South African Muslims.” Available online: $\mathrm{http} / /$ halalmedia.net/halal-pork-scandal-enrages-south-africa-muslims/ (accessed on 28 December 2012).

50. BBC News Africa. "South African Muslims Furious at 'Pork Scandal'." Available online: http://www.bbc.co.uk/news/world-africa-15753835 (accessed on 28 December 2012).

51. Shaheed Tayob. "Unpacking Halal Contamination." The Voice of the Cape , 10 March 2012. Available online: http://www.vocfm.co.za/index.php?option=com_k2\&view=item\&id=3677: unpacking-halal-cross-contamination\&Itemid=134 (accessed on 28 December 2012).

52. "BBC News Look North: HMC Exposed." BBC News. Available online: $\mathrm{http}: / /$ www.youtube.com/zwatch?v=M-vya2dPzaE (accessed on 28 December 2012).

53. Halal-AVS. "Fraude: Presence des produits carnés non-certifiés par AVS-(Grill House)." Available online: http://www.halal-avs.com/Article.aspx?id=272 (accessed on 28 December 2012).

54. Halal-AVS. "Usage non-autorisé de la marquee AVS—Silver Sushi, Saint Denis)." Available online: http://www.halal-avs.com/Article.aspx?id=267 (accessed on 28 December 2012).

55. Halal-AVS. "Attention: la boucherie Falguière refuse de retirer la marque AVS après sa résiliation."Available online: http://www.halal-avs.com/Article.aspx?id=271 (accessed on 28 December 2012).

56. Mon-Islam. Available online: http:/www.mon-islam.com/reseau-social/groupes/viewdiscussion/ 162-la-soci\%C3\%A9t\%C3\%A9-sioniste-isla-d\%C3\%A9lice-condamn\%C3\%A9.html?groupid=75 and also Observatoire Halal, http://www.observatoireduhalal.com/15052010-zaphirisla-delice- 
ou-le-leader-de-la- $\% \mathrm{C} 2 \% \mathrm{AB}$-charcuterie- $\% \mathrm{C} 2 \% \mathrm{BB}$-halal-en-danger $\% \mathrm{E} 2 \% 80 \% \mathrm{~A} 6 /$ (accessed on 28 December 2012).

57. Al Kanz. Available online: http://www.al-kanz.org/2010/08/30/isla-delice-avs-rumeur/ (accessed on 28 December 2012).

58. “Communiqué sur l'affaire Isla Delice." AVS-France, 20 September 2011. Available online: http://www.avs.fr/PrintArticle.aspx?id=147 (accessed on 28 December 2012).

59. Halal-AVS. Available online: http://www.halal-avs.com/Article.aspx?journal=127\&id=274 (accessed on 29 December 2012).

60. Katibin. Available online: http://www.katibin.fr/2012/11/27/isla-delice-et-avs-divorcent-2/ (accessed on 29 December 2012).

61. Al-Kanz. Available online: http://www.al-kanz.org/2012/11/23/isla-delice-avs/ (accessed on 29 December 2012).

62. Asidcom. Available online: http://www.asidcom.org/Les-dessous-de-l-affaire-ISLA.html (accessed on 29 December 2012).

63. CELAT/ULAVAL. Available online: http://www.celat.ulaval.ca/wp-content/uploads/2012/10/ Programme-Colloque-Halal-r\%C3\%A9acualis\%C3\%A9-12-octobre.pdf (accessed on 29 December 2012).

64. Point de Bascule-Canada. Available online: http://pointdebasculecanada.ca/articles/ 10002817-colloque-sur-le-halal-\%C3\%A0-montr\%C3\%A9al-\%E2\%80\%93-subventionn\%C3\% A9-par-des-institutions-publiques-participation-de-tariq-ramadan.html (accessed on 29 December 2012).

65. Je mange Halal. Available online: http://www.jemangehalal.com/personnalites-halal/fethallahotmani.php (accessed on 29 December 2012).

66. Brahami, Mostafa, and Fethallah Otmani. Le marché du Halal: Entre Références Religieuses \& Contraintes Industrielles. Saint-Etienne: Tawhid/AVS Press, 2010, p. 206.

67. See Otmani, Fetallah. "Commentaires de Fethallah Otmani d'AVS au sujet de. L'article 'le Halal' publié par le site salafs.com." http://www.avs.fr/pub/602.pdf.

68. Turner, Brian. "Introduction: The price of piety." Contemporary Islam: Special Issue on Piety, Politics, and Islam 2 (2008): 1-6.

69. Nasir, Kamaludeen Mohamed, and Alexius A. Pereira. "Defensive Dining: Notes on the Public Dining Experiences in Singapore." Contemporary Islam: Special Is sue on Piety, Politics, and Islam 2 (2008): 61-73.

70. See also: Nasir, Kamaludeen Mohamed, Alexius A. Pereira, and Bryan S. Turner. Muslims in Singapore: Piety, Politics and Policies. London: Routledge, 2010.

71. Such Halal Cosmopolitanism is also promoted by Spring Singapore, a massive Halal consultant group replete with a "Lifestyle division" and various assistance schemes. Amongst their greatest attempts to "globalize Halal" is the ingenious creation of Halal dim sum. See their report "Global Halal Industry: Guide to Tapping the Fast Growing Halal Food Market.” Spring Publications, Singapore, 2011, http://www.spring.gov.sg/EnterpriseIndustry/IP/FM/Documents/Global_Halal _Food_Industry.pdf. 
72. Marranci, Gabriele. "Defensive or offensive dining? Halal dining practices among malay muslim singaporeans and their effects on integration." The Australian Journal of Anthropology 23 (2012): 84-100.

73. Halal Advocates of America. Available online: http://halaladvocates.net/site/ourresources/people-of-the-book/ (accessed on 10 January 2013).

74. Halal Transactions of Omaha. Available online: http://halaltransactions.org/about-us/ (accessed on 10 January 2013).

75. Halal Transactions of Omaha. Available online: http://halaltransactions.org/article-slaughteringby-the-people-of-the-book/ (accessed on 10 January 2013).

76. Islam Revolution. Available online: http://www.islamrevolution.org/halalmeat.htm (accessed on 10 January 2013).

77. Mufti Abdur-Rahman ibn Yusuf. "Zabiha-Meat Madness." Available online: http://www.ilmgate.org/zabiha-meat-madness/ (accessed on 10 January 2013).

78. Islam News Room. “Is Mcdonalds's Halal?" Available online: http://islamnewsroom.com/newswe-need/36-is-mcdonalds-halal (accessed on 10 January 2013).

79. Haenni, Patrick. L'Islam de Marché: L'autre Révolution Conservatrice. Paris: Seuil, 2005.

80. Arabian Centres. Available online: http://www.arabiancentres.com/shopping-categorynew.php? $\mathrm{m}=10 \& \mathrm{c}=8$ (accessed on 10 January 2013).

81. "Paris Hilton Avoids Dubai Jail Rome with Middle Eastern Cultural Experts." The Daily Telegraph, 1 July 2009, http://www.dailytelegraph.com.au/entertainment/paris-hilton-avoidsdubai-jail-with-middle-eastern-cultural-experts/story-e6frewyr-1225744354896.

82. "Paris Hilton to be Guest of Honour at Dubai Bash." Arabian Business, 18 May 2011,

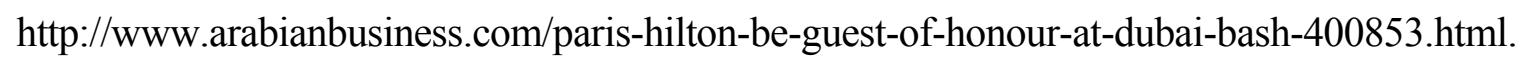

83. Victor. Paris, France. Personal Communication. 20 August 2008.

84. Davies, Catriona, and Latifa Azdi. Paris Hilton whips up a storm in holy Meca. Available online: http://edition.cnn.com/2012/11/20/world/meast/paris-hilton-store-mecca/index.html (accessed on 10 January 2013).

85. Omar Baloch. "Paris Hilton's New Store at Mecca Mall in Saudi Arabia." Available online: $\mathrm{http} / /$ www.youtube.com/watch?v=P9pfnu58YUU (accessed on 12 January 2013).

86. Crescent Tours. "Halal Tourism." Available online: http://www.crescenttours.com/ pages/halal_tourism (accessed on 12 January 2013).

87. Nasreen Suleaman. "The birth of halal holidays." The Guardian, 28 August 2010. http://www.guardian.co.uk/travel/2010/aug/28/halal-holidays-turkey-muslim-women.

88. Al Arabiya News. "Egypt's Islamists Offer Controversial Vision for Halal Tourism." Al Arabiya, 13 December 2011. Available online: http:/www.alarabiya.net/articles/2011/12/13/182316.html (accessed on 12 January 2013).

89. Brighelli, Jean-Paul. La Fabrique du Crétin: La Mort Programée de L'école . Paris: Gallimard/Folio, 2005.

90. Janardhan, N. "Politics on the Rocks with a Twist of Religion." Asia Times, 24 January 2003. http://www.atimes.com/atimes/Middle_East/EA24Ak01.html. 
91. Jaillette, Jean-Claude. "Marine Le Pen: 'Tout le viande Français est devenue Halal'." Marianne, 19 February 2012. http://www.marianne.net/Marine-Le-Pen-Toute-la-viande-francaise-estdevenue-halal_a215753.html.

92. “Halal: Dhuicq avait soulevé l'ambigüité en 2010." L'est-éclair, 22 February 2012. $\mathrm{http}: / / \mathrm{www}$.lest-eclair.fr/article/actualites/halal-dhuicq-avait-souleve-lambiguite-en-2010.

93. "Halal/Le Pen: Totalement faux (Guéant)." Le Figaro, 19 February 2012. http://www.lefigaro.fr/flash-actu/2012/02/19/97001-20120219FILWWW00187-halalle-pentotalement-faux-gueant.php.

94. Noémie Destelle. "Marine Le Pen dénonce les hamburgers Halal de Quick." Liberation, 15 February 2010. http://www.liberation.fr/societe/0101619507-marine-le-pen-denonce-leshamburgers-halal-de-quick.

95. Resistance Republicaine. Available online: http://www.resistancerepublicaine.eu/ (accessed on 20 January 2013).

96. Français de France. Available online: http://francaisdefrance.wordpress.com/2011/08/03/halalnous-allons-connaitre-le-double-apartheid/ (accessed on 20 January 2013).

97. "Quick teste les hamburgers halal dans huit restaurants." Le monde, 17 February 2010. http://www.lemonde.fr/societe/article/2010/02/17/quick-teste-les-hamburgers-halal-dans-huitrestaurants_1307527_3224.html.

98. Guylain Chevrier. "Quick joue la restauration islamique contre la République laïque.” Riposte Laïque, 24 February 2010. http://ripostelaique.com/Quick-joue-la-restauration.html.

99. Laborde, Cécile. Critical Republicanism and Political Philosophy. Oxford: Oxford University Press, 2008.

100. Al-Kanz. Available online: http://www.al-kanz.org/2010/02/17/quick-roubaix-halal/ (accessed on 20 January 2013).

101. Badiou, Alain. Ethics: An Essay on the Understanding of Evil . Translated by Peter Hallward. New York: Verso, 2001.

102. Olivier Roy. Globalized Islam: The Search for a New Ummah. New York: Columbia University Press, 2004.

103. UNESCO. Available online: http://www.unesco.org/culture/ich/RL/00437?lg=en\&pg=00173\#TOC1 (accessed on 20 January 2013).

104. "French gastronomic meal joins UNESCO heritage list." France24, 18 November 2010. $\mathrm{http}: / / w w w . f r a n c e 24 . c o m / e n / 20101116$-french-gastronomic-meal-joins-unesco-heritage-listcommittee-france-food.

105. Barthes, Roland. Mythologies. Translated by Annette Lavers. New York: Noonday Press, 1992.

106. Kebab-Frites.com. Available online: http: //www.kebab-frites.com/news/combien-de-caloriesdans-un-kebab-115.html (accessed on 20 January 2013).

107. Fatema Mernissi. Islam and Democracy: Fear of the Modern World . Translated by Mary Jo. Lakeland. Cambridge: Perseus Press, 2002.

108. Eagleton, Terry. After Theory. New York: Basic Books, 2003.

(C) 2014 by the author; licensee MDPI, Basel, Switzerland. This article is an open access article distributed under the terms and conditions of the Creative Commons Attribution license (http://creativecommons.org/licenses/by/3.0/). 